\title{
Comparison of seismic performances of reinforced concrete frames strengthened by different techniques
}

\author{
Mehmet Baran ${ }^{\text {a* }}$ (D) \\ a Department of Civil Engineering, Ankara Yıldırım Beyazıt University, Ankara 06050, Turkey. Email: mehmet.baran@ybu.edu.tr \\ * Corresponding author
}

https://doi.org/10.1590/1679-78256340

\begin{abstract}
The aim of this study is to compare the seismic performances of strengthening techniques applied to reinforced concrete (RC) non-ductile frames tested under the effects of seismic loads. In the experimental part of the study, one-third scale, one-bay, two-storey non-ductile hollow brick infilled RC frames were strengthened with five different techniques and tested under reversed cyclic lateral loads. One being reference, five of the frames were infilled with hollow bricks and plastered on both sides, one was strengthened with plain mortar, one was strengthened with steel fiber reinforced mortar, two were strengthened with precast RC plates. The last frame was strengthened with RC infill wall. Strengthening techniques increased strength and stiffnesses of the frames in the ranges from $57 \%$ to $189 \%$ and from $186 \%$ to $486 \%$ respectively. In the numerical analysis part, an existing RC non-ductile building located in Istanbul, strengthened with the techniques, were analyzed using a computer program. Numerical results were evaluated in terms of interstorey drift ratio together with the overall seismic performance of the building.
\end{abstract}

\section{Keywords}

Strengthening, hollow brick infill wall, plain mortar, steel fiber reinforced mortar, precast reinforced concrete $(\mathrm{RC})$ plate, reinforced concrete $(\mathrm{RC})$ infill wall, seismic performance.

\section{Graphical Abstract}
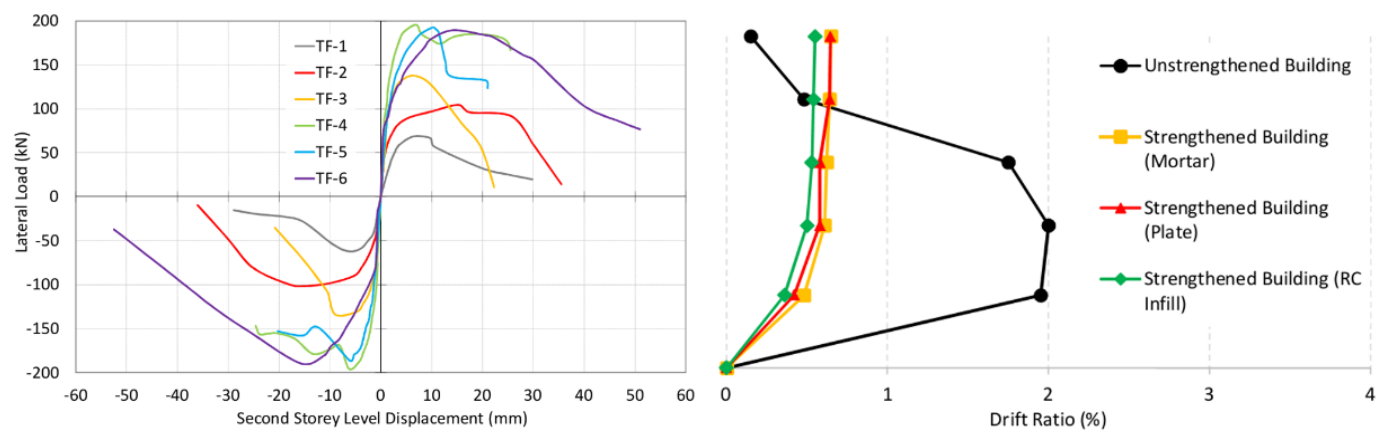


\section{INTRODUCTION}

Countries located on seismically active zones like Turkey had suffered extensive social and economic damages with destructive earthquakes. Lack of knowledge during design and construction stages together with poor workmanship had turned the scenes to disasters after earthquakes. It was realized that major cause of damage in structures in Turkey and its neighbour countries have been stemming from inadequate lateral stiffness. The most effective way of satisfying the drift requirements of such buildings is providing adequate number of cast-in-place RC infill walls such that lateral stiffness of the building is increased. However, this technique involves messy construction works and therefore evacuation of the building is required. Since there is great building stock waiting for strengthening before a major earthquake struck, researchers have been continuously working on strengthening techniques convenient for RC structures being in use. Related studies have focused currently on techniques in which hollow brick infill walls are strengthened using various materials, instead they are replaced with RC walls.

Many studies on more feasible, rapid and easy techniques, in which evacuation of the structure is unnecessary, have been successfully implemented in Turkey and in other countries. Studies on strengthening of masonry infill walls using CFRP (Carbon Fiber Reinforced Polymer), shotcrete with mesh reinforcement, steel fiber reinforced mortar, prefabricated panel infills, and steel plates may be listed accordingly. In addition to these techniques, innovative materials such as textiles, ferrocement, epoxy and grout injection (National Information Centre for Earthquake Engineering, 1986; Oliveira et al., 2012) have also been used in strengthening of masonry infill walls by various researchers. All offer different alternatives for seismic strengthening. Among them, CFRP is the most popular technique investigated so far. Quick application, low weight over strength ratio and high resistance to tough environmental conditions are its advantages. Among some researchers, Ozcebe et al. (2003), Antoniades et al. (2005), El-Dakhakhni et al. (2006), ElGawady et al. (2006a), Erdem et al. (2006), Altin et al. (2008a), Garcia et al. (2010), Akin et al. (2011), Zhu et al. (2011) and Hadigheh et al. (2014) conducted experimental and analytical studies in which RC frames were strengthened using polymers. In all these studies, it was concluded that strengthening using polymers significantly increased lateral load and energy absorption capacities of the frames. In addition, it was pointed out that type and number of FRP anchors had major influence on the behaviour of strengthened walls and effectiveness of CFRP application depends on the efficiency of the anchorages between the laminates and the wall. It should also be taken into account that CFRP is an expensive material, requires qualified workmanship during application and low fire resistance of FRP sheets and relatively expensive epoxy adhesive needed to bond FRP sheets to the wall are the disadvantages of this technique making it less common in daily applications.

Use of composite materials such as textile reinforced mortar (TRM) which comprises open-mesh high-strength textiles (i. e. carbon, glass, basalt) have many advantages over FRP systems such as more resistance to high temperature (Tetta and Bournas, 2016; Raoof and Bournas, 2017a, b). In the studies conducted by Triantafillou and Papanicolaou (2006), Papanicolaou et al. (2007), Papanicolaou et al. (2008), De Felice et al. (2014), Koutas et al. (2014), Askouni and Papanicolaou (2017), Akhoundi et al. (2018), Koutas and Bournas (2019) and Koutas et al. (2019), it was concluded that the use of textile reinforced mortar increases both in-plane and out-of-plane bending capacities whereas ductilities of stone and masonry walls. In addition, use of TRM have also advantages like its compatibility with concrete or masonry walls, practical application at low temperatures or on wet surfaces and lowered costs.

Bonding of prefabricated panel is also a popular hollow masonry infill wall strengthening technique. In the studies conducted by Baran and Tankut (2011a, b), precast concrete panels were bonded on to plastered hollow bricks by means of epoxy material and it was proven experimentally that this technique is very effective in increasing the stiffness, lateral load and energy dissipation capacities of infilled RC frames whereas improving their seismic behaviour. Panels were also used by Kahn and Hanson (1979), Kaldjian and Yuzugullu (1983), Frosch et al. (1996), Frosch (1999), Kesner and Billington (2005), Okuyucu (2011), Akin and Sezer (2016), Aksoylu and Sezer (2018), and Aksoylu and Kara (2020) in examining the behaviour of infilled frames. It was shown that the use of panels is an effective and convenient method to improve the frame strength and stiffness while reducing costs and saving of time.

Kahn (1984) strengthened masonry walls using reinforced shotcrete, Acun and Sucuoglu (2005) tested one-third scaled two-storey one-bay RC frames whose hollow brick infills were strengthened using welded wire mesh reinforced mortar. The effects of using steel reinforced shotcrete on the behaviour of masonry walls were investigated in the studies conducted by ElGawady et al. (2004) and ElGawady et al. (2006b). Altin et al. (2010) tested 1/3 scaled one-storey onebay non-ductile RC frames where hollow brick infill walls were strengthened using plastered reinforcement layers. Korkmaz et al. (2010) tested nonductile $1 / 2$ scaled two-storey one-bay infilled RC frames strengthened with the application of external mesh reinforcement and plaster where Sevil (2010) and Sevil et al. (2011) strengthened plastered hollow brick infill walls using steel fiber reinforced mortar with $2 \%$ content of fibers. In all these studies, it was concluded that 
adding an extra mortar layer on masonry infill walls is an effective strengthening technique in increasing lateral load carrying and energy dissipation capacities of the test specimens.

Strengthening with steel fiber reinforced mortar or shotcrete is a promising technique from structural and economical aspect points of view, researchers verged to use steel to strengthen masonry infills since using steel strips would most probably lower the difficulties and disturbance given to occupants during application of adding an extra mortar layer on masonry infill walls. In the studies conducted by Taghdi et al. (2000a, b), four full-scale, low-rise masonry wall specimens were strengthened by adding two diagonal steel strips on each wall face and two vertical steel strips added as boundary elements on each side of the walls. In the experimental research program conducted by Farooq et al. (2006), it was undertaken to ascertain the compressive and shear strength enhancement of masonry wall panels using steel strips and it was concluded that the technique is viable for rehabilitation of old deteriorating buildings and strengthening of unreinforced masonry structures in seismic zones. An important experimental study was conducted by Altin et al. (2008b), in which a full scale one storey masonry building with window and door openings was manufactured and tested on the shaking table by applying increased amplitude free vibration. In the study, it was concluded that steel straps reduced the natural period of the earthquake damaged masonry building and prevented the failure of the building at the same amplitude of free vibration. Altin et al. (2012) compared the results of four strengthening techniques applied to non-ductile low rise RC frames under seismic loads and they concluded that strengthening of masonry infill walls with steel strips was the most effective technique from lateral strength and initial stiffness increase point of view. In the study conducted by Ozbek and Can (2012), the considerable positive effect of the flag plates in the corners of the wall were proved on the behaviour of hollow brick walls strengthened using diagonal steel angles.

The aim of this study is to determine and compare the relative seismic performances of RC frames strengthened with five different strengthening techniques. Test results were evaluated in terms of strength, stiffness, interstorey drift ratio, energy dissipation capacity, specimen failure mode, ease of application and cost economy point of views. In the numerical part, a non-ductile RC framed building having inadequate lateral stiffness modelled using a finite element based computer program were analyzed and overall seismic performances of the building strengthened with different techniques were examined in detail.

\section{RESEARCH SIGNIFICANCE}

There are numerous studies on strengthening of non-ductile RC frames having inadequate lateral stiffness with various techniques in the literature. However, there exists limited number of studies in which seismic performances of these strengthening techniques were compared in all aspects. In the present study, experimental findings from RC frames strengthened with five different strengthening techniques were compared to each other from structural performance, ease of application and cost economy points of view. In addition, numerical analysis of a non-ductile RC framed building having inadequate lateral stiffness and then strengthened with the aforementioned techniques were carried out using a finite element program and the structural performance levels of this building obtained from numerical analyses were compared to each other.

\section{EXPERIMENTAL PROGRAMS}

\subsection{Details of test specimens}

Dimension and reinforcement details of the test frames are illustrated in Figure 1. Geometry and reinforcement details of all test frames are identical. Non-ductile, one-bay, two-storey RC frames having inadequate lateral stiffness are intentionally designed as defect to simulate the common deficiencies encountered in most of the buildings in Turkey and in many countries. Inadequate lateral stiffness, low concrete strength, use of plain bars in columns and beams, connections with weak column-strong beam combination, inadequate confinement at column and beam ends and nonconfined beam-column connections are the major deficiencies. Free ends of beam and columns stirrups have $90^{\circ}$ hooks. Columns and beams have dimensions of $100 \times 150 \mathrm{~mm}$ and $150 \times 150 \mathrm{~mm}$, respectively. Longitudinal reinforcement used for columns and beams are four and six plain bars with $8 \mathrm{~mm}$ diameter respectively where stirrups are $4 \mathrm{~mm}$ plain bars with a spacing of $100 \mathrm{~mm}$ for columns and beams. 


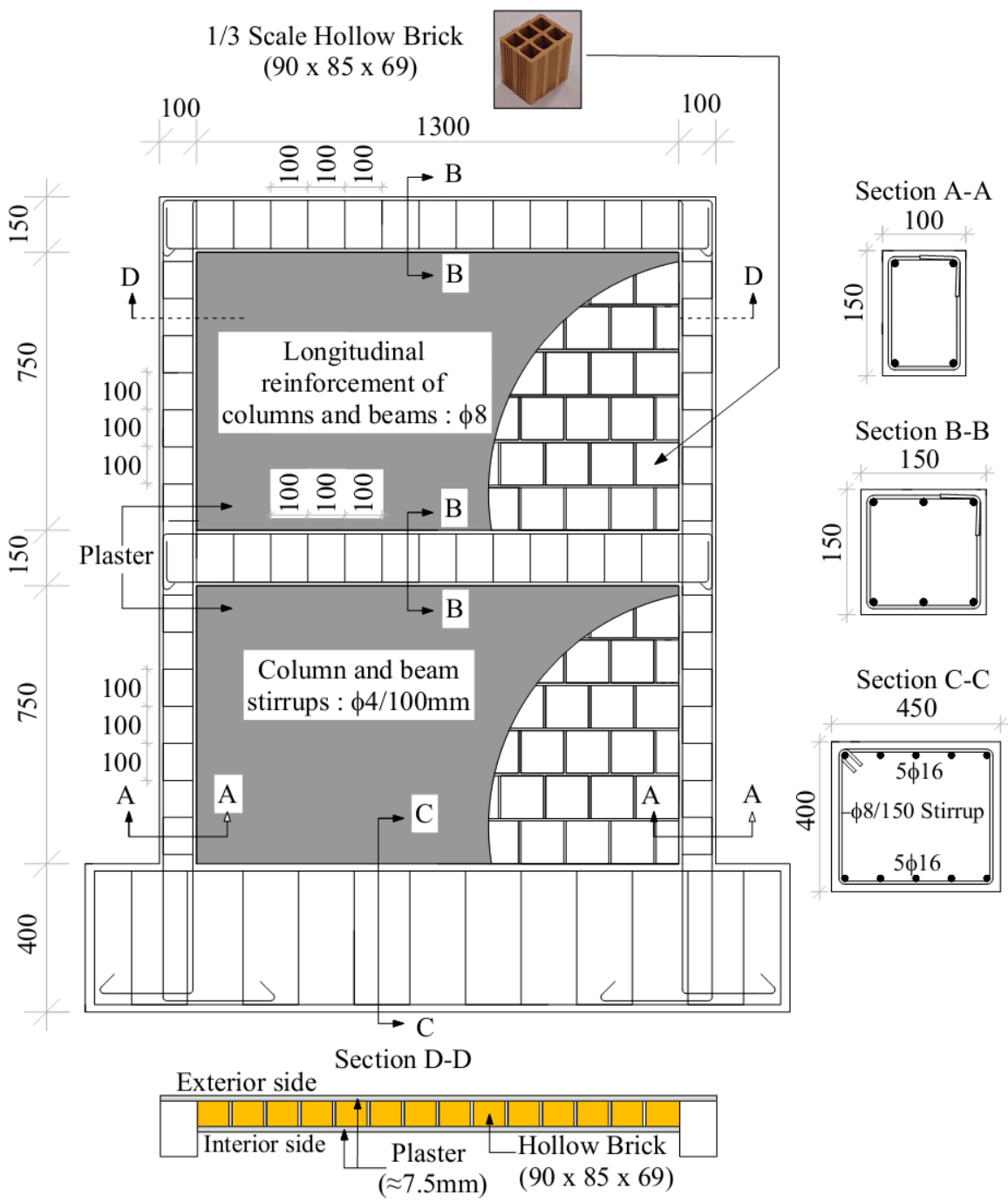

Figure 1 Details of the Test Frames (Dimensions in $\mathrm{mm}$ ).

As given in Table 1 summarizing the properties of the test frames, Test Frame-1 is a reference specimen where the remaining five are strengthened with a) plain mortar, b) steel fiber reinforced mortar, c) precast $\mathrm{RC}$ rectangular plate, d) precast RC strip plate and e) RC infill wall instead of hollow brick infills, respectively. Except the Test Frame-6, all specimens were infilled with hollow bricks of one-third scale having dimensions of $90 \times 85 \times 69 \mathrm{~mm}$. The ratio of the net area to that of the gross area of the hollow bricks was 0.51 . Both faces of the hollow brick infill walls were plastered with the same mortar material of the same batch. Total thickness of the hollow brick infill walls including plasters on both sides were nearly $85 \mathrm{~mm}$. Hollow bricks, which are narrower than the RC frame, were placed eccentrically on the frame to form a plane surface (exterior side) together with the beams and columns in order to reflect the common practice. On the exterior side, infills were plastered together with beams and columns whereas only infills were plastered on the interior side. Details of the strengthening techniques are given in Table 1.

Test Frame-2 and Test Frame-3 were strengthened with overlaying of plain mortar and mortar with $2 \%$ volumetric ratio of steel fiber on to the interior side of plastered hollow brick infills at both stories, respectively (Figure 2). Plain mortar used in Test Frame-2 and 2\% steel fiber reinforced mortar used in Test Frame-3 had compressive strengths of 40.8 MPa and 20.9 MPa, respectively. High variation in between two mortar strength values can be attributed to the curing conditions, temperature difference on casting days and water content difference of aggregate kept outside the laboratory which was exposed to outer climate conditions. In order to maintain the force, transfer between the frame members and the strengthened infills, dowels of $8 \mathrm{~mm}$ diameter deformed bars, $180 \mathrm{~mm}$ in length, were embedded $60 \mathrm{~mm}$ into columns and beams at both stories at a spacing of $200 \mathrm{~mm}$ for both test frames. Diameter of dowel holes were $12 \mathrm{~mm}$. After anchoring, interior sides of the infills of Test Frame-2 were covered with $20 \mathrm{~mm}$ thick plain mortar whereas interior infills of Test Frame-3 were covered with $20 \mathrm{~mm}$ thick steel fiber reinforced mortar (2\% volumetric ratio). 
Table 1 Test Frames.

\begin{tabular}{|c|c|c|c|c|}
\hline \multirow{2}{*}{ Frame No } & RC Frame & Plaster & \multirow{2}{*}{ Hollow Brick Infill } & \multirow{2}{*}{ Strengthening Technique } \\
\hline & $\mathrm{f}_{\mathrm{c}}(\mathrm{MPa})$ & (MPa) & & \\
\hline 1 & 16.6 & 6.5 & Yes & Reference - No Strengthening \\
\hline 2 & 8.6 & 6.0 & Yes & Plain Mortar \\
\hline 3 & 13.6 & 7.6 & Yes & Steel Fiber Reinforced Mortar \\
\hline 4 & 15.6 & 4.9 & Yes & Precast RC Rectangular Plate \\
\hline 5 & 16.2 & 5.4 & Yes & Precast RC Strip Plate \\
\hline 6 & 15.0 & - & No & RC Infill Wall \\
\hline
\end{tabular}

Test Frames- 4 and Test Frames- 5 were strengthened by bonding of precast RC plates having dimensions of $320 \mathrm{~mm}$ $\times 245 \mathrm{~mm}$ and $105 \mathrm{~mm} \times 740 \mathrm{~mm}$, respectively. Thickness of both plate types were $20 \mathrm{~mm}$, and all plates were bonded on to the plastered infills at both stories via two-component epoxy, Sikadur-31 (Sika, 2001) of 2 mm thickness. RC plates were precast in the laboratory using steel molds. Wire mesh of $\mathrm{f3} / 50$ type, easily can be found in the market, were used as reinforcement of a single layer in the production of plates. Rectangular plates used in Test Frame-4 and strip plates used in Test Frame-5 had compressive strengths of $33.4 \mathrm{MPa}$ and $32.0 \mathrm{MPa}$, respectively. RC plates were intendedly designed to be cast with high strength concrete in order that they can supply the required strength to test frames cast with low strength concrete. In order to transfer the shear force to the foundation, dowels of $8 \mathrm{~mm}$ diameter deformed bars, $250 \mathrm{~mm}$ in length, were embedded $100 \mathrm{~mm}$ into rigid foundation. Five dowels were used (spacing was $320 \mathrm{~mm}$ ) for Test Frame-4 whereas thirteen dowels were used (spacing was $105 \mathrm{~mm}$ ) for Test Frame-5. Diameter of the dowel holes were $10 \mathrm{~mm}$ for both test frames. For both frames, since precast RC plates were bonded on the plaster by the use of a strong two-component adhesive and it was thought that hollow brick infills together with the plates would behave as a rigid infill due to strong adhesion of plates to plastered infill, it was concluded that dowels to be used only at the foundation level with the aim of minimizing the workmanship. The use of dowels in between all individual plates were seen to be redundant. The spacing in between RC plates and anchorage bars were filled with the two-component epoxy, Sikadur-31 which have a compressive strength of $20 \mathrm{MPa}$. Strengthening process was finished with the filling of these spacings such that no extra plastering of the infill was needed. Details of the strengthening techniques are illustrated in Figure 3.
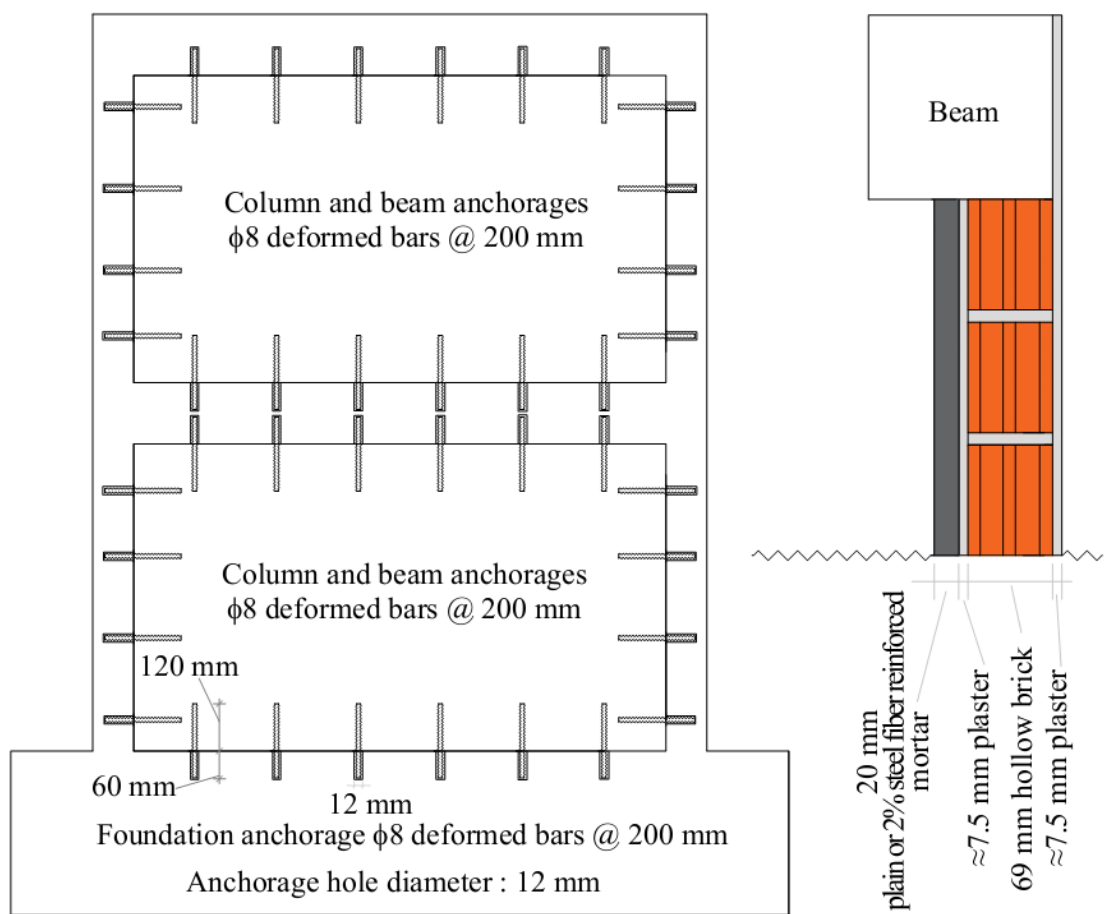

TEST FRAME-2 \& TEST FRAME-3

Figure 2 Strengthening with mortar (plain or steel fiber ( $2 \%$ volumetric ratio) reinforced). 
Test Frame- 6 was strengthened with $60 \mathrm{~mm}$ thick cast-in-place RC infill wall added at both stories. RC infills were cast symmetrically in the plane of loading. Details of this technique (RC infill wall) is illustrated in Figure 4. Compressive strength of concrete used as RC Infill was $23.1 \mathrm{MPa}$. Reinforcement of RC infills were prepared in the laboratory as $\mathrm{f6} / 150 \mathrm{~mm}$ plain bars for both directions (in wire mesh layout). In order to maintain the force transfer between the frame members and the RC infill, dowels of $10 \mathrm{~mm}$ diameter deformed bars, $250 \mathrm{~mm}$ in length, were embedded $70 \mathrm{~mm}$ into columns and beams at both stories at a spacing of $250 \mathrm{~mm}$. Diameter of the dowel holes were $12 \mathrm{~mm}$. They were cleaned firstly with a metal brush and then with compressed air. After cleaning, they were then filled with epoxy (Spit Epcon System, 2005) and anchorage bars were placed. Reinforcement of the RC infill was mechanically fixed to anchorage bars.
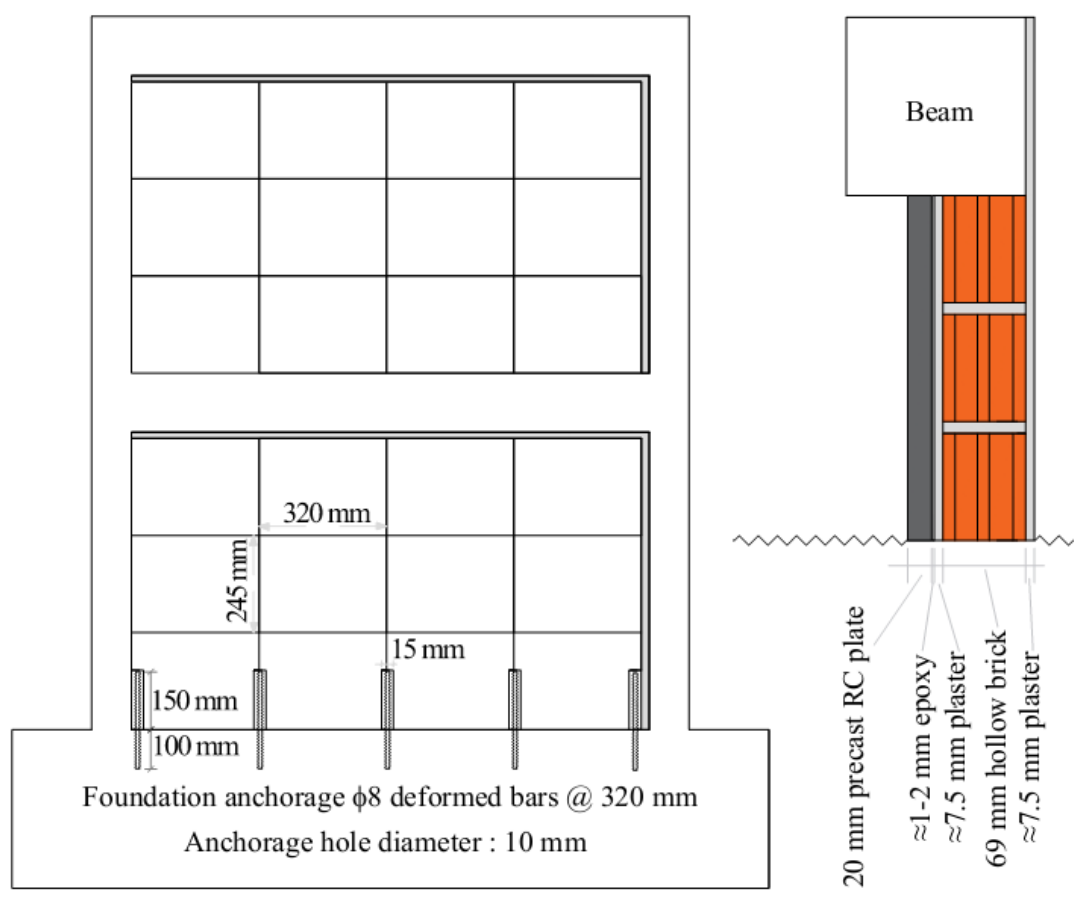

TEST FRAME-4

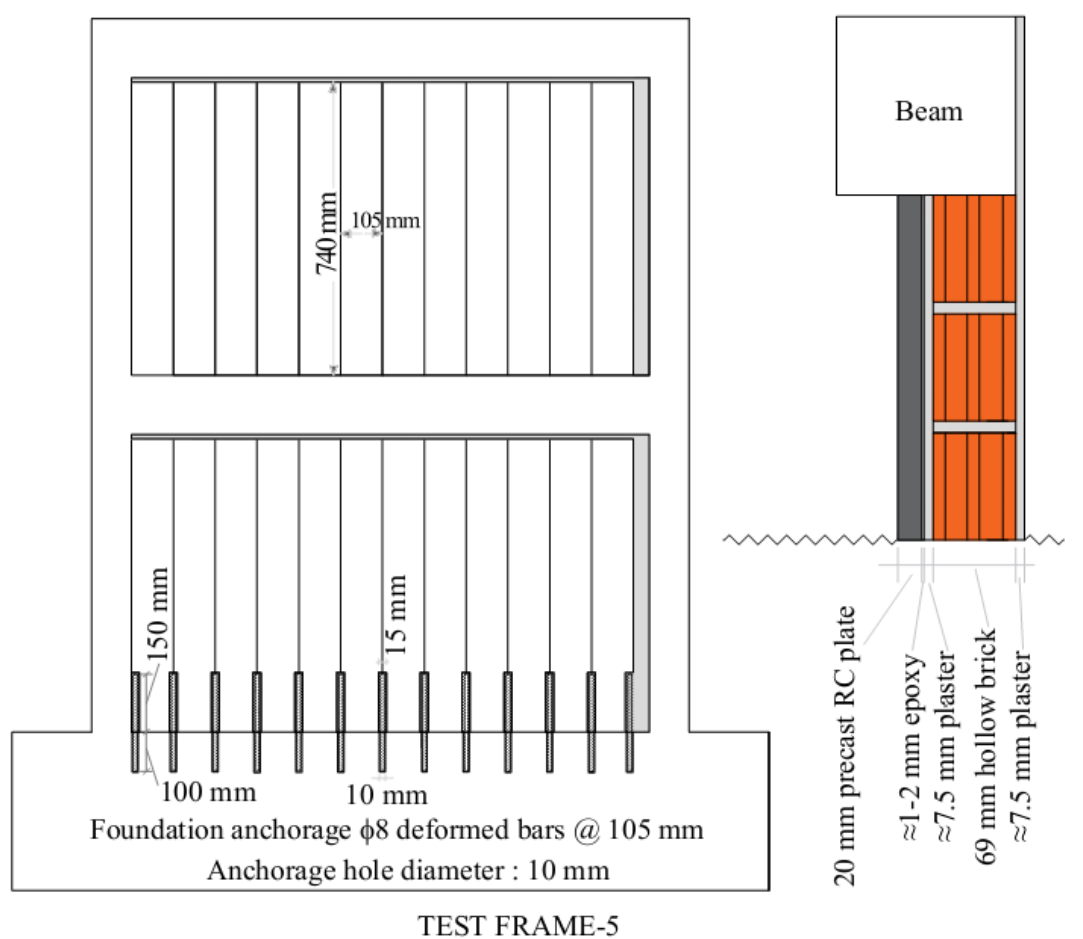

Figure 3 Strengthening with precast RC plates (rectangular plate - strip plate). 


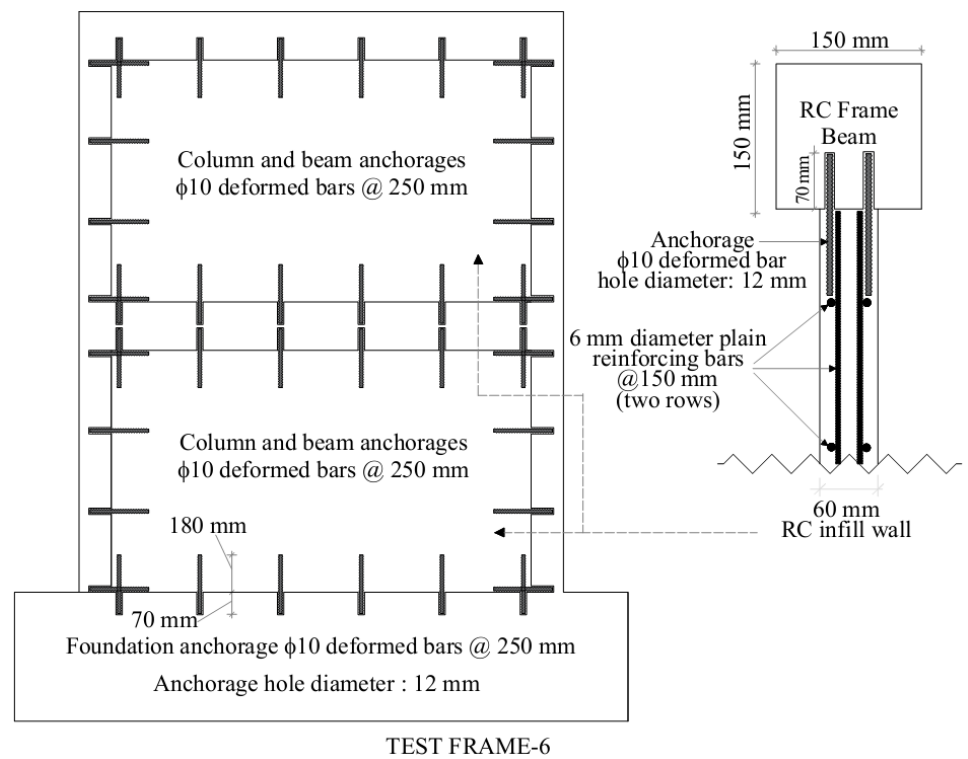

Figure 4 Strengthening with RC infill walls.

The design aim for the strengthened specimens was to attain yielding in columns' longitudinal bars in the first storey together with an overall ductile flexural behaviour of the test specimens. Although there was not any specific target strength aimed in the present study, strength, and stiffness of the Test Frame- 6 (Strengthened with RC infill wall) would form the upper bound for all the specimens. Geometric dimensions and details were chosen according to the design philosophy summarized above. While applying the strengthening techniques, details were chosen such that they can be applied easily and economically.

\subsection{Materials}

Concrete compressive strengths, given in Table 1, were obtained on the testing days of RC frames. In order to simulate the existing building stock, test frames were intentionally designed to have low concrete compressive strengths of 12 to $15 \mathrm{MPa}$, which was the average value encountered in the real market for the deficient buildings in Turkey. Unexpectedly, concrete compressive strength of the Test Frame-2 came out to be lower than the remaining RC frames. This variation can be attributed to temperature difference and water content difference of aggregate which was kept outside the laboratory exposed to outer climate conditions. Lower concrete compressive strength of the frame had a negative influence on the frame behaviour but the negative influence was limited due to plastered hollow brick infills enhancing RC frame behaviour. In addition, there exist buildings in the real market in Turkey with a concrete compressive strength of $8 \mathrm{MPa}$, which can be encountered with a high probability. The average concrete compressive strength of all test frames came out to be 14.3 MPa on the testing day. The concrete strength of the RC infill was $23.1 \mathrm{MPa}$ for Test Frame-6. In Table 1, concrete compressive strengths are given. In the present study, reinforcements having similar properties were used in all the specimens since the strengthening techniques took place in different test groups. Reinforcement properties are given in Table 2.

Table 2 Mechanical properties of reinforcement.

\begin{tabular}{ccccc}
\hline Bar Diameter $(\mathbf{m m})$ & Location & $\mathbf{f}_{\text {sy }}$ (MPa) & $\mathbf{f}_{\text {su }}$ (MPa) & Type \\
\hline 3 & RC Plate Reinforcement (TF-4, TF-5) & 670 & 750 & Plain \\
4 & Column and Beam Stirrups (TF-1, TF-4, TF-5) & 220 & 355 & Plain \\
4 & Column and Beam Stirrups (TF-2, TF-3, TF-6) & $\sim 270$ & $\sim 390$ & Plain \\
6 & RC Infill Wall Reinforcement (TF-6) & $\sim 330$ & 445 & Plain \\
8 & Column and Beam Longitudinal Reinforcement (TF-1, TF-4, TF-5) & 330 & 445 & Plain \\
8 & Column and Beam Longitudinal Reinforcement (TF-2, TF-3) & 365 & $\sim 510$ & Plain \\
8 & Column and Beam Longitudinal Reinforcement (TF-6) & 405 & 545 & Plain \\
8 & Anchorage Bars (TF-4, TF-5) & 350 & 470 & Deformed \\
8 & Anchorage Bars (TF-2, TF-3) & $\sim 560$ & $\sim 780$ & Deformed \\
10 & Anchorage Bars (TF-6) & $\sim 520$ & - & Deformed \\
\hline
\end{tabular}

TF indicates Test Frame 
Mix proportions for mortar, plaster, precast RC plate and RC infill are given in Table 3. For Test Frame-2 and Test Frame-3, mortar used in between the hollow bricks and mortar used for plastering of both interior and exterior sides had similar proportion ratios where the same mortar was used for Test Frame-1, Test Frame-4 and Test Frame-5. Mortar compressive strengths for all test frames are given in Table 1 where the average value was calculated to be $5.5 \mathrm{MPa}$. Considering the gross area, compressive strength of hollow bricks was calculated as $8.5 \mathrm{MPa}$ in the direction of the holes and as 2.8 MPa in the perpendicular long direction (Baran and Sevil 2010).

Table 3 Mix proportions for mortar, plaster, precast RC plate and RC infill.

\begin{tabular}{ccccc}
\hline \multirow{2}{*}{ Material } & \multicolumn{3}{c}{ Percent by Weight (\%) } \\
\cline { 2 - 5 } & RC Plate & Plain Mortar ${ }^{*}$ ) & 2\% SFR Mortar & RC Infill Wall \\
\hline Cement & 19.05 & 23.4 & 22.0 & 39.0 \\
$0-3$ mm Aggregate & 37.75 & 63.8 & 60.0 & 35.0 \\
$3-7$ mm Aggregate & 32.55 & - & - & 17.0 \\
Water & 10.48 & 12.8 & 12.0 & 9.0 \\
Plasticizer & 0.17 & 0.043 & 0.040 & - \\
Steel Fiber & - & - & 6 & - \\
\hline
\end{tabular}

${ }^{*}$ Test Frame-2

SFR indicates Steel Fiber Reinforced Mortar

\subsection{Test setup and instrumentation}

Test configuration of the specimens, loading system and instrumentation is illustrated in Figure 5. Test Frames were tested under reversed cyclic lateral loads simulating earthquake effects. To solve the lateral load distribution problem, the lateral load was applied on a spreader beam at one-third of its span in a triangular manner simulating earthquake effect. Lateral load supplied by the hydraulic jack in 2:1 ratio to both stories to ensure that the lateral load at the second floor level always remains twice as the lateral load at the first floor level. Total lateral load applied was measured with a load cell. Capacity of the hydraulic jack was $600 \mathrm{kN}$ in compression whereas $420 \mathrm{kN}$ in tension. A steel guide frame was constructed around the test specimen in order to prevent out-of-plane deformations. The columns in the long direction were connected to each other by steel box sections. In the short direction the columns were connected by steel $L$ sections. The connection of the steel frame with the test specimen was conducted at second storey level by means of four rollers attached to the box sections and gently touching the test frame. Rollers permitted horizontal as well as vertical in plane movement of the test frames. Up to maximum load capacity, loading controlled cycles were applied where displacement-controlled loadings were applied for further cycles in non-linear region. The lateral load level was the same for the forward and backward half cycles and was increased nearly 10 $\mathrm{kN}$ at every full cycle up to displacement-controlled cycles. The same loading history were intended to be applied on the specimens, however backward and forward half cycle loadings were controlled by second storey level displacements when the response of the test frames became non-linear. Test frames attained different capacities, showed different failure mechanisms and behaviour due to the differences in details of the strengthening techniques. For this reason, different displacementcontrolled loading cycles were applied on the specimens. Tests were considered to be complete when a definite second-storey level displacement was reached. Second-storey level displacement vs. lateral load were monitored during tests. An axial load corresponding to nearly $15 \%$ of column's axial load capacity was applied on each column using prestressed tendons. Storeylevel displacements were measured by Linear Varible Displacement Transducers (LVDT) whereas rigid body rotations and shear deformations of the infill walls were measured by mechanical Dial Gauges (DG). At each cycle, newly formed cracks were marked on the specimens and failure mechanisms were observed.

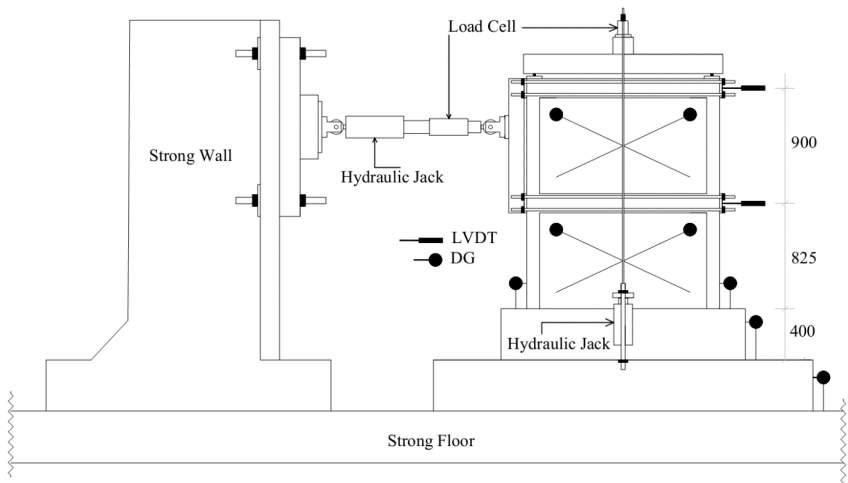

Figure 5 Test setup and instrumentation (dimensions in $\mathrm{mm}$ ). 


\section{BEHAVIOUR AND FAILURE MODE OF TEST FRAMES}

Lateral load - Second storey level displacement graphs of specimens are illustrated in Figure 6 . As can be seen from these graphs, all techniques increased lateral strength, stiffness, and energy dissipation capacities of strengthened test frames.

\subsection{Test frame-1 (Reference, TF-1)}

In the cycles prior to maximum loading, X-shaped shear cracks occurred in the diagonal compression zones of the first storey hollow brick infill wall of the reference specimen. Test Frame-1 attained a lateral load of $66.6 \mathrm{kN}$ at $0.43 \%$ first storey drift ratio. Test was ended up when the specimen lost its load carrying capacity with the crushing of the upper corners of the hollow brick infill wall under diagonal compression. Specimen failed with reaching to high storey drift ratios after exceeding maximum load. Relatively larger shear cracks occurred at column-beam connections of the first-storey due to poor confinement of these regions. Photograph of Test Frame-1 after the test is illustrated in Figure 7.

\subsection{Test frame-2 (Plain mortar, TF-2)}

Although plain mortar layer applied on the interior side of the infill increased lateral strength and stiffness to a limited extend, Test Frame-2 could be able to carry the applied lateral loads to nearly $3 \%$ first storey drift ratio values with critical cracks occurring on the plain mortar layer without any separation from the plastered infill wall. Test Frame2 reached a lateral load level of $104.5 \mathrm{kN}$ at $1.24 \%$ first storey drift ratio. Separation in between the strengthened infill and the foundation was observed at nearly $1 \%$ first storey drift ratio. Shear cracks occurred at the plain mortar layer and at poorly confined column-beam connections. Despite the anchorage bars added at both storey levels with the aim of having a monolithic behaviour of strengthened infill together with the RC frame, an effective shear force transfer between these two could not be formed due to inadequate adherence between the plastered infill wall and the newly added mortar layer. Hollow bricks fell down at nearly $4 \%$ first storey drift ratio and the test was terminated. Photograph of Test Frame-2 after the test is illustrated in Figure 7.
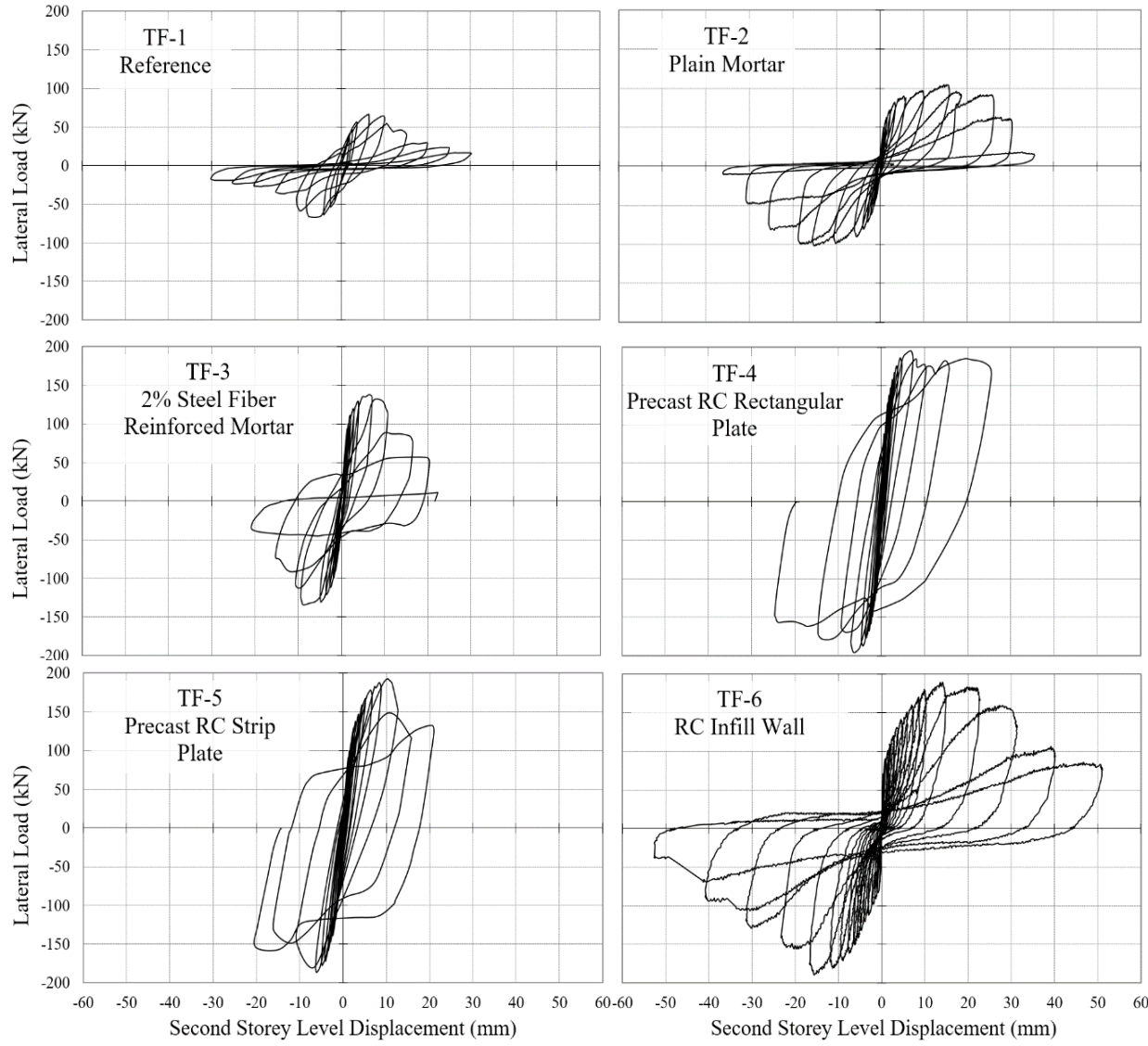

Figure 6 Lateral load-second storey level displacement graphs of all test frames. 


\subsection{Test frame-3 (2\% Steel fiber reinforced mortar, TF-3)}

The first crack at the first storey column-beam connection was followed up with the flexural cracks occurred on the columns. With increasing lateral loads, cracks were formed on the plaster of the exterior side. A crack extending from the bottom corner to the middle of the first storey beam occurred on the plain mortar layer at $0.2 \%$ first storey drift ratio. This crack initiated an increase in shear deformations, extra shear crack occurrence at column-beam connections and column base cracks. Test Frame-3 reached a lateral load level of $140.4 \mathrm{kN}$ at $0.56 \%$ first storey drift ratio. At this lateral load level, separation between the first storey infill and the first storey beam occurred and flexural cracks were observed on this beam. After the maximum load cycle, severe damage was observed on the first storey frame members, cover concrete of columns fell off where longitudinal reinforcement of columns buckled. Column ends of the low strength RC frame suffered damage since shear forces were carried from the infill wall to the RC frame by means of diagonal compression struts. Photograph of the Test Frame-3 after the test is illustrated in Figure 7.

\subsection{Test frame-4 (Precast RC rectangular plate, TF-4)}

Following the column base cracks, separations were observed in plate-RC frame foundation level together with the column bending cracks, and the bending cracks in the middle region of the columns expanded and moved towards the front faces of the columns. Although no cracks were observed on the plates up to the thirteenth forward cycle loading level ( 175 $\mathrm{kN})$, a diagonal crack occurred on one of the lowest row plates of the first storey infill. Test Frame-4 reached a lateral load level of $195.7 \mathrm{kN}$ at $0.53 \%$ first storey drift ratio. Beginning with the sixteenth forward cycle, displacement-controlled loading cycles started to be carried out, separation in between the first storey beam - plates and a diagonal crack just below the first storey beam were observed. In the proceeding few cycles, separations were observed at the second storey beam plate and second storey column - plate connections where crushing occurred on one of the lowest row plates of the first storey infill. The test was terminated with an acceleration in the crushing at the base of one of the columns in the last cycle. The anchorage bars embedded only at the foundation level in between RC plates came out to be insufficient to transfer the shear forces between the strengthened infill and RC frame. If complete use of anchorage bars in between RC plates at four sides of both stories were provided, there would be a significant improvement in behaviour such that an intended cantilever beam behaviour (monolithic RC frame-infill wall behaviour) would be exhibited by this frame and failure was dominated by flexure instead of shear. Photograph of the Test Frame-4 after the test is illustrated in Figure 7.

\subsection{Test frame-5 (Precast RC Strip Plate, TF-5)}

With the start of the test, separations in between the first storey column - plate connections, cracks on the columns and plaster cracks on the exterior side of the frame were observed in the few first cycles. In the following cycles, new flexural cracks on the columns and separations in between the frame foundation - plate connections were observed. In the tenth forward and backward loading cycle, shear cracks were formed at the first-floor column - beam connections. In the next cycle, separations in between the second storey column - plate connections and diagonal cracks on the first storey plates were observed. From this moment on, Test Frame- 5 cannot carry more lateral load and displacement-controlled loading cycles were carried. In the next loading cycle, crushing occurred at the column - beam connections and plaster pieces broke off and fell down. In the later phases of the test, diagonal cracks on the first storey plates expanded and cracks at first storey column - beam connections turned into shear failure. Test Frame- 5 reached a lateral load level of $192.7 \mathrm{kN}$ at $0.66 \%$ first storey drift ratio. As in the case of Test Frame-4, the anchorage bars embedded only at the foundation level in between RC plates came out to be insufficient to transfer the shear forces between the strengthened infill and RC frame. Complete use of anchorage bars in between RC plates at four sides of both stories would improve the behaviour significantly and Test frame- 5 would exhibit an intended cantilever beam behaviour (monolithic RC frame-infill wall behaviour), as in the case of Test frame-4. Photograph of Test Frame-5 after the test is illustrated in Figure 7.

\subsection{Test frame-6 (RC infill wall, TF-6)}

The first hairline cracks on Test Frame- 6 were observed at the locations where mesh reinforcement of the first storey RC infill wall was placed. In the ongoing first loading cycles, cracks on the columns, separations at the first storey RC infill - foundation connection level and diagonal cracks on the first storey RC infill wall were observed. In the tenth loading cycle, new cracks were formed on both RC infill walls and the separation at the first storey RC infill - foundation connection level became more apparently. Test Frame- 6 reached a lateral load level of $189.7 \mathrm{kN}$ at $0.79 \%$ first storey drift ratio. From this stage on, displacement-controlled loading cycles started to be carried out, column longitudinal reinforcements buckled, crushing at the column bases and at the concrete of first storey RC infill - foundation connection level occurred. Since this frame exhibited cantilever beam behaviour (monolithic RC frame-infill wall behaviour), anchorage bars embedded to all frame members proved to be sufficient for transferring the shear forces between the RC infill and frame members. Photograph of Test Frame- 6 after the test is illustrated in Figure 7. 

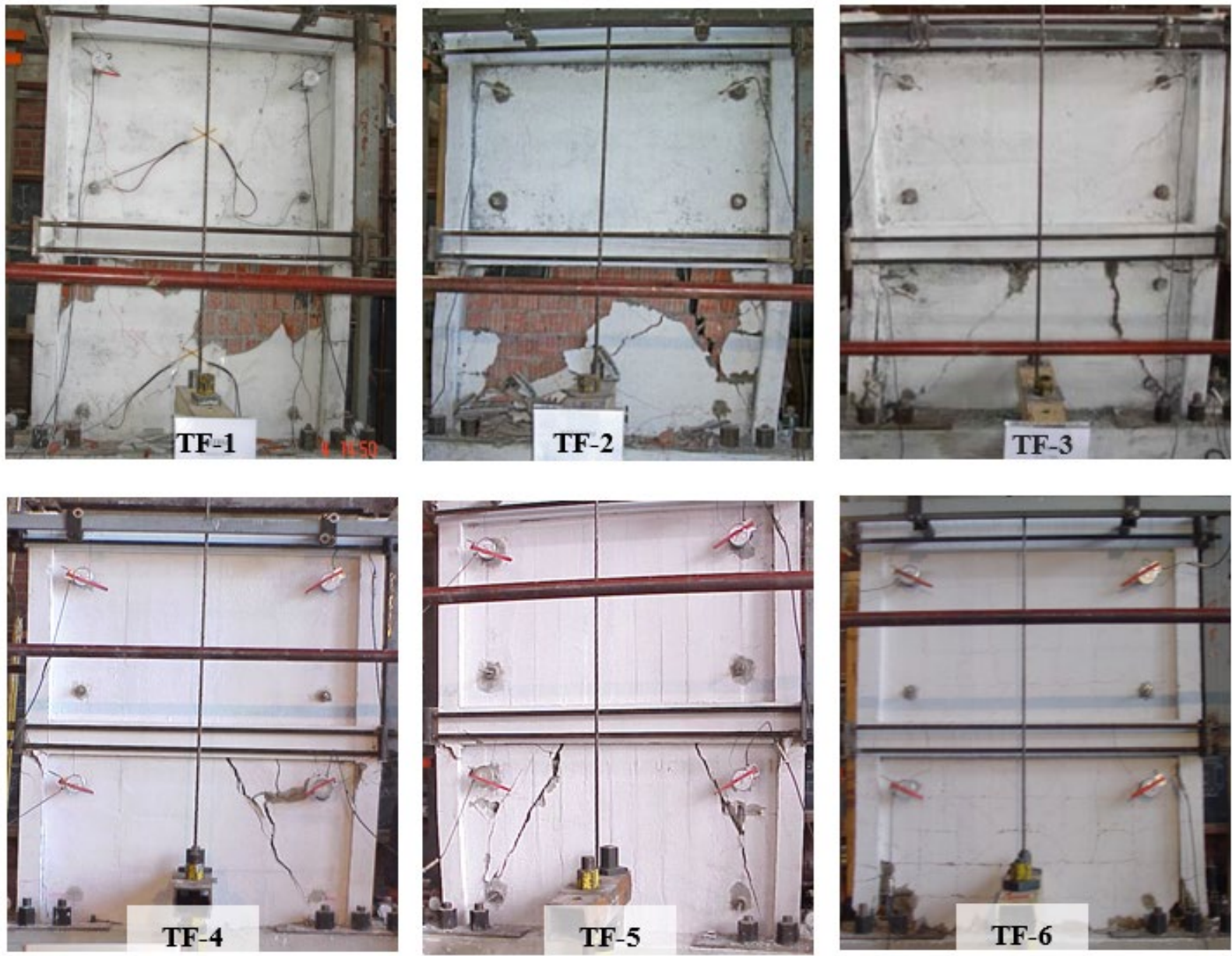

Figure 7 Photographs of all frames after tests.

\section{DISCUSSION OF EXPERIMENTAL RESULTS}

Test results were summarized and illustrated in Table 4. Comparison values in this table was prepared to illustrate the effect of each strengthening technique on ultimate strength, initial stiffness, interstorey drift ratio at ultimate and energy dissipation capacities of all frames and compare their effectiveness relatively.

Table 4 Summary of test results.

\begin{tabular}{|c|c|c|c|c|c|c|c|c|c|}
\hline \multirow{2}{*}{$\begin{array}{l}\text { Test } \\
\text { Frame }\end{array}$} & \multicolumn{2}{|c|}{$\begin{array}{l}\text { Lateral Load Capacity } \\
\text { (kN) }\end{array}$} & \multirow[b]{2}{*}{ Ratio } & \multirow{2}{*}{$\begin{array}{c}\text { First Storey } \\
\text { Interstorey } \\
\text { Drift Ratio } \\
\text { (\%) }\end{array}$} & \multirow{2}{*}{$\begin{array}{c}\text { Second } \\
\text { Storey } \\
\text { Interstorey } \\
\text { Drift Raito } \\
\text { (\%) } \\
\end{array}$} & \multirow{2}{*}{$\begin{array}{c}\text { Initial } \\
\text { Stiffness } \\
\text { (kN/mm) }\end{array}$} & \multirow[b]{2}{*}{ Ratio } & \multirow{2}{*}{$\begin{array}{l}\text { Energy } \\
\text { Dissipation } \\
\text { Capacity } \\
\text { (kN.m) }\end{array}$} & \multirow[b]{2}{*}{ Ratio } \\
\hline & $\begin{array}{l}\text { Forward } \\
\text { Loading }\end{array}$ & $\begin{array}{c}\text { Backward } \\
\text { Loading }\end{array}$ & & & & & & & \\
\hline TF-1 & 66.6 & 66.6 & 1.00 & 0.43 & 0.32 & 21.4 & 1.00 & 4.5 & 1.00 \\
\hline TF-2 & 104.5 & 101.5 & 1.57 & 1.24 & 0.55 & 61.1 & 2.86 & 10.8 & 2.40 \\
\hline TF-3 & 140.4 & 134.2 & 2.11 & 0.56 & 0.24 & 67.2 & 3.14 & 9.43 & 2.10 \\
\hline TF-4 & 195.7 & 195.7 & 2.94 & 0.53 & 0.29 & 118.7 & 5.55 & 20.4 & 4.53 \\
\hline TF-5 & 192.7 & 186.5 & 2.89 & 0.66 & 0.53 & 109.8 & 5.13 & 17.8 & 3.96 \\
\hline TF-6 & 189.7 & 189.4 & 2.85 & 0.79 & 0.69 & 125.3 & 5.86 & 21.5 & 4.78 \\
\hline
\end{tabular}

Response envelope curves illustrated in Figure 8, which were constructed by connecting the peak points of each forward and backward cycles of the load-displacement curves, will be used for evaluating strength and stiffness characteristics of all frames. As can be seen from this figure, strength and stiffness of strengthened specimens came out to be significantly higher than those of reference. Each strengthening technique were proved to have different level of effectiveness on RC frames. The lowest lateral load carrying capacity was observed in the case of Test Frame-2 whereas 
the highest was seen in the case of Test Frame-4. Although anchorage bars were embedded in all RC frame members at both stories in Test Frame-2 and Test Frame-3, an effective shear force transfer between RC frame members and mortar layer could not be formed due to inadequate adherence between the plastered infill wall and the newly added mortar layer. In the cases of Test Frame-4 and Test Frame-5, anchorage bars were embedded in between plates only at the foundation level resulting with an inadequate shear force transfer between frame- strengthened infill and both tests were terminated with the progress of diagonal cracks at the first storey infills. Lateral load carrying capacities of Test Frame-2 and Test Frame-3 were 57\% and 111\% higher than that of reference, respectively. These ratios are $194 \%$ and 189\% higher for Test Frame-4 and Test Frame-5, respectively. Test Frame-6, which forms the upper bound for the strengthened specimens, attained a lateral load carrying capacity that is $185 \%$ higher than that of reference. Bonding of Precast RC Plates by means of a strong two-component adhesive on plastered infills enhanced the shear resisting mechanism in carrying compressional and tensional loads. Therefore, lateral load carrying capacity of Test Frame- 4 came out to be identical to that of Test Frame- 5 and both frames carried slightly more loads than Test Frame- 6 which was strengthened with RC infills.

Although Test Frame- 2 and Test Frame- 3 could not attain performances as effective as Test Frame- 4 and Test Frame5 from lateral strength and initial stiffness points of view, especially Test Frame-2 showed more ductile behaviour as compared to the other three. In the cases of Test Frame-4 and Test Frame-5, tests were terminated a few loading cycles later than the ultimate load cycle before reaching to high displacements. Test Frame- 6 strengthened with RC infill behaved satisfactorily from lateral load carrying capacity and ductility points of view. The design aim for the strengthened specimens was to attain a definite lateral load carrying capacity followed by yielding in columns' longitudinal reinforcements. Finally, lateral load carrying capacities of all strengthened frames were reached but strength of specimens came out to be different due to differences in the details of the strengthening techniques. Test Frame- 4 and Test Frame-5 slightly exceeded the lateral load carrying capacity of Test Frame- 6 (forming the upper bound for the strengthened frames) where Test Frame- 2 and Test Frame- 3 could not be able to reach these lateral load levels. This can be attributed to the fact that the strong two-component epoxy, used in Test frame- 4 and Test frame- 5 turned the plastered hollow brick infill into a rigid infill-epoxy-plate trio behaving like an RC infill as in the case of Test frame- 6 .

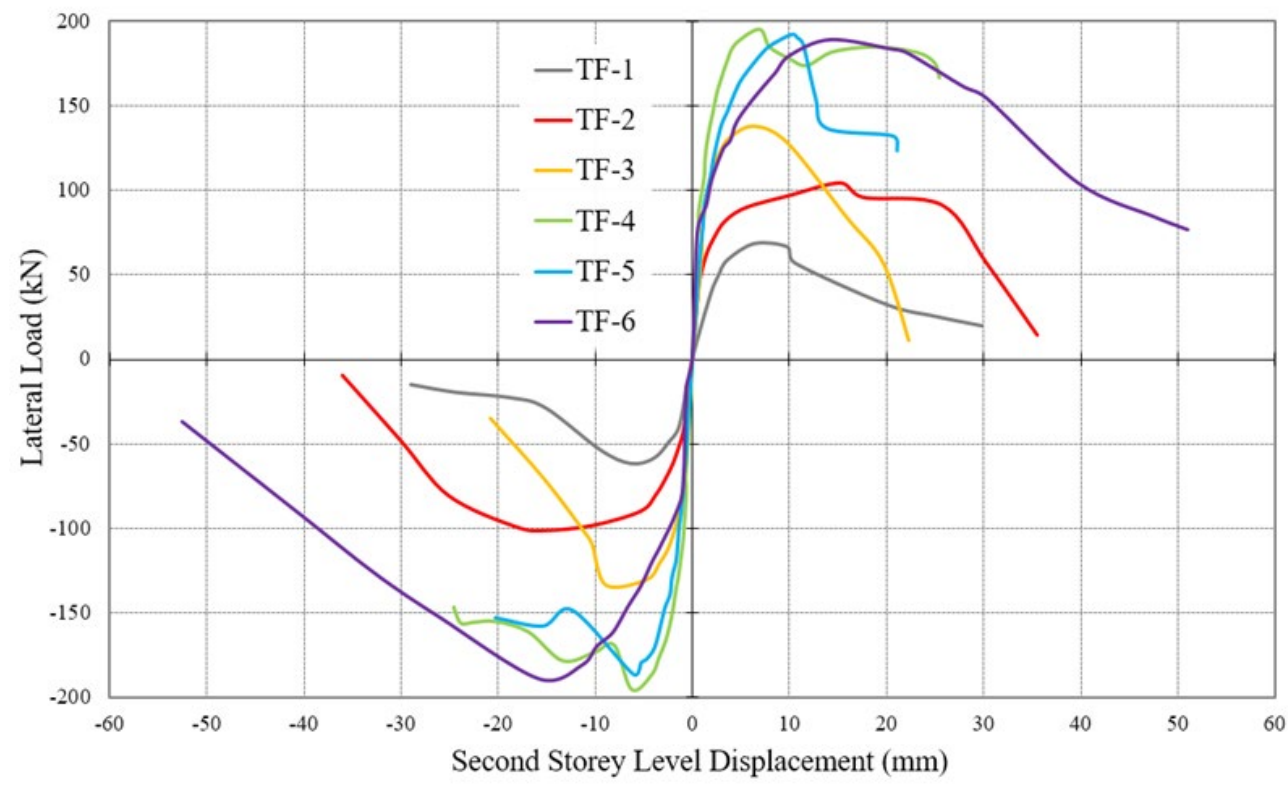

Figure 8 Response envelopes of all frames.

In Turkish Building Earthquake Code (2018), maximum storey drift ratio is calculated using the following Equation 1:

$\lambda \frac{\delta^{X}{ }_{i, \max }}{h_{i}} \leq 0.008 \kappa$

where; $\lambda$ is a coefficient calculated for the prevailing vibration period in the direction of the earthquake for the building, $\delta^{\mathrm{X}}{ }_{\text {,max }}$ is the maximum reduced relative interstorey drift, $\mathrm{h}_{\mathrm{i}}$ is the height of the $\mathrm{i}^{\text {th }}$ floor of the building and $\mathrm{k}$ is taken as 1.0 for an RC framed structure. By this equation, maximum storey drift ratio is specified as $\sim 0.008$. Every regulation 
specifies similar limits such that damage at structural and non-structural members are prevented and second order effects are minimized. As it can be seen in Table 4, each strengthened test frame reached its maximum lateral load carrying capacity before the first storey drift ratio reached to maximum value specified by Turkish Building Earthquake Code (2018), except from Test Frame-2. It can be said that frame strengthening techniques increased stiffnesses of the frames resulting in reduced interstorey drifts. Beyond peak, strength degradation was much more significant in Test Frame-3 and Test Frame- 5 as compared to other strengthened frames which the degradation levels were comparatively less. Storey drift ratios for all strengthened specimens at the ultimate load level came out to be larger than that of reference Test Frame-1. The smallest and largest first storey drift ratios were $0.53 \%$ and $1.24 \%$ for Test Frame- 4 and Test Frame-2, respectively.

Initial slope of lateral load - second storey level displacement curve in the first forward half cycle is accepted as the initial stiffness of a test frame and it is a good indicator for comparing the seismic behaviour of test frames. The increase in the initial stiffnesses of the strengthened test frames varied between $186 \%$ and $486 \%$ as compared to that of the reference (Table 4). The largest increase was observed in Test Frame-6 (RC infill wall) where it was nearly as high as in the cases of Test Frame- 4 and Test Frame- 5 (strengthened with precast RC plates) with an average value of $\sim 435 \%$. This can be attributed to the fact that the strong two-component adhesive, which was used for bonding plates on plastered infills, obviously enhanced the shear resisting mechanism in carrying compressional and tensional loads. The increase was nearly $200 \%$ in average for Test Frame-2 and Test Frame-3 (strengthened with plain and $2 \%$ steel fiber reinforced mortar) due to inadequate adherence between the plastered infill wall and the newly added mortar layer.

The amount of dissipated energy was calculated as summing the areas under lateral load-second storey level displacement curve of a test frame for all forward-backward cycles and is a good indicator for seismic effectiveness of a strengthening technique. The increase in the dissipated energy values of Test Frame- 2 and Test Frame-3 (plain and $2 \%$ steel fiber reinforced mortar) with respect to reference Test Frame- 1 varied between $110 \%$ and $140 \%$ where the increase varied between $296 \%$ and $353 \%$ for Test Frame- 4 and Test Frame- 5 (precast RC rectangular and strip plates). The increase in energy dissipation capacities of this two test frames (Test Frame-4 and Test Frame-5) was as nearly high as that of Test Frame-6 (RC infill wall) which can be attributed to the fact that precast RC plates were bonded on the plaster by the use of a strong two-component adhesive by which hollow brick infills together with the plates behaved as rigid as an RC infill due to strong adhesion of plates to plastered infill. The increase was not as that high as in the cases of Test Frame-2 and Test Frame-3 (strengthened with plain and $2 \%$ steel fiber reinforced mortar) but an increase of $125 \%$ in average occurred. As expected, the maximum increase of $378 \%$ was observed in the case of Test Frame- 6 strengthened with RC infills.

Average increase in lateral load carrying capacity and initial stiffness of the strengthened specimens with respect to reference masonry infilled reference frames obtained from the experiments conducted by other researchers are given in Table 5. As can be seen in this table, an average value for the increase in lateral strength and initial stiffness values were obtained as 1.8 and 4.4 respectively for fiber reinforced mortar strengthening whereas these values were 2.5 and 2.5 respectively for plate strengthening, 2.7 and 6.3 respectively for RC Infill strengthening. If the increase in lateral strength and initial stiffness values for the test frames of the present study given in Table 4 are examined, it can easily be concluded that the increase in lateral load carrying capacity obtained in this study are consistent with the other studies conducted by other researchers. There is no direct consistency in terms of stiffness point of view since the initial stiffness of a test frame is dependent on some parameters such as the quality of the workmanship in the construction of the hollow brick infill wall and plastering of the specimen, which played an important role in the displacement history in early cycles.

Table 5 Test results of the experiments conducted by other researchers

\begin{tabular}{ccc}
\hline Strengthening method-researcher & Lateral strength increase (Ratio) & Stiffness increase (Ratio) \\
\hline Polypropylene Fiber Reinforced Mortar-Sevil (2010) & 1.8 & 4.4 \\
Hybrid Fiber Reinforced Mortar-Sevil (2010) & 1.8 & 4.4 \\
Plate-Okuyucu (2011) & 2.1 & 2.0 \\
Mesh Reinforced Plaster-Altin et al.(2012) & 1.5 & 1.8 \\
RC Infill-Altin et al. (2012) & 2.7 & 6.3 \\
Plate-Akin and Sezer (2016) & 3.1 & 6.8 \\
Plate-Aksoylu and Sezer (2018) & 1.8 & 2.1 \\
Plate-Aksoylu and Kara (2020) & 2.9 & 3.8 \\
\hline
\end{tabular}




\section{NUMERICAL STUDY}

Modelling of plastered hollow brick infills strengthened by mortar (plain or $2 \%$ steel fiber reinforced) or precast RC plates (rectangular or strip) is more complex than hollow brick infill modelling, especially when anchorages are taken into account. In this study it is assumed that mortar or plate strengthened infill behaves as a diagonal compression strut as taken into account by Smith and Carter (1969) in their study. Upon lateral load application, separation in between the RC frame and the infill occurs over a partial length of the column and the beam and the contiguity between them retains adjacent to two opposite corners. At this instant, a line drawn from one loaded corner to the other represents the direction of compression. Therefore, it can be assumed that the infill behaves as a diagonal strut adequately representing the load transfer mechanism. Therefore, strengthened test frames can be analyzed with two independent diagonal compression struts which the first is replacing the plastered hollow brick infill and the second replacing the strengthening mortar or plate. The modelling of a diagonal compression strut is shown in Figure 9 , where $\mathrm{I}$ and $\mathrm{h}$ are the geometric dimensions of the infill, $a$ and $b$ are the interaction distribution factors, $w$ is the width of the stress distribution along the diagonal compression strut and $a$ is the effective width of the strut.

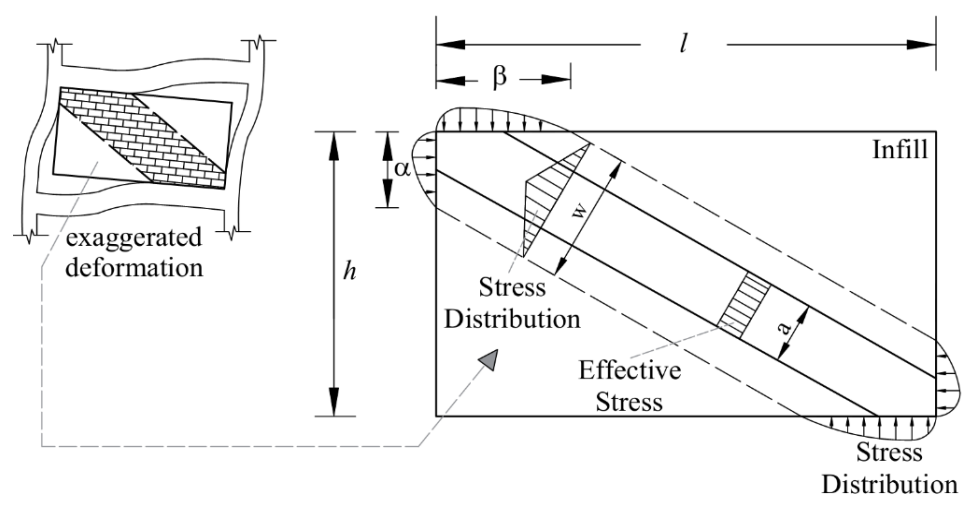

Figure 9 Equivalent diagonal compression strut modelling.

\subsection{Modelling of plastered hollow brick infill}

In the numerical studies conducted, plastered hollow brick infills, modelled as diagonal compression struts, were represented by compressional elastic-brittle bars without a tensile strength. To determine the axial strength and stiffness of the strut modelling the plastered infill wall, test specimens of wall panels having dimensions of $700 \mathrm{~mm} \times 700 \mathrm{~mm}$ were tested in the laboratory under diagonal compression. At the end of the tests, the average strength and modulus of elasticity in the diagonal direction of the wall panels were calculated as $f_{c, \text { infill }}=4.5 \mathrm{MPa}$ and $\mathrm{E}_{\text {infill }}=7000 \mathrm{MPa}$. Therefore, axial strength and stiffness of the equivalent diagonal compression strut modelling the plastered hollow brick infill can be calculated according to Equation 2 (Baran et al. 2010) and Equation 3 (FEMA 356 (2000)), respectively:

$F_{c, \text { infill }}=f_{c, \text { infill }} \cdot a_{\text {infill }} \cdot b_{w}$

$k_{\text {infill }}=\frac{a_{\text {infill }} \cdot b_{w} \cdot E_{\text {infill }}}{d}$

where $f_{c, \text { infill }}$ is the compressive strength of the infill, $a_{\text {infill }}$ is the effective width of the strut, $b_{w}$ is the thickness of the infill, $F_{c, \text { infill }}$ is the axial load-carrying capacity of the strut, $E_{\text {infill }}$ is the modulus of elasticity of the infill, $d$ is the diagonal length of the infill and $k_{\text {infill }}$ is the rigidity of the strut. As a result, strength and initial stiffness values of the compression strut modelling the plastered hollow brick infill were taken as $62.5 \mathrm{kN}$ and $69.4 \mathrm{kN} / \mathrm{mm}$ in the numerical studies. The load-deformation curve of the first compression strut modelling the plastered hollow brick infill is given Figure 10.

\subsection{Modelling of strengthening material layer (plain/2\% steel fiber reinforced mortar and strip/rectangular precast RC plate)}

The second compression strut models plain/2\% steel fiber reinforced mortar and precast RC rectangular/strip plate, as a strengthening layer. Since this layer can be considered as a homogeneous and isotropic material; the geometrical properties of the second strut can be calculated using the method proposed by Smith and Carter (1969). In order to be 
able to model this layer, pushover analysis was conducted to compare the results of twenty RC framed test specimens (Baran et al. 2013). Inelastic plane frame computer program DRAIN-2DX (Allahabadi and Powell, 1988) was used for the pushover analyses of the test frames. The software accepts the axial load-moment interaction curve as yield surface for columns and elasto-plastic moment hinges for beam ends. For the struts, compression/tension link element with zero tensile capacity was used.

The load carrying capacity of the equivalent diagonal compression strut modelling the strengthening material layer can be calculated using Equation 4:

$F_{c}=\lambda \cdot f_{c} \cdot a_{s m l} \cdot b_{w, s m l}$

where $\mathrm{Fc}$ is the lateral load-carrying capacity of the equivalent compression strut, $\lambda$ is a constant dependent on mortar or plate strength, $\mathrm{f}_{\mathrm{c}}$ is the compressive strength of mortar or plate, $\mathrm{a}_{\mathrm{sml}}$ is the width of the equivalent compression strut modelling the strengthening material layer (sml) that was given in the study made by Smith and Carter (1969) and $b_{\mathrm{w}, \mathrm{sml}}$ is the thickness of the equivalent compression strut modelling the sml layer and accepted to be $20 \mathrm{~mm}$ (applied thickness of the sml).

In the study conducted by Baran et al. (2013), pushover analyses were conducted to be able to define values for the constant $\lambda$ in equation 4 for mortar and plate strengthening techniques, respectively. For this purpose, displacement controlled non-linear pushover analyses were performed for different values of $\lambda$. Since the same mortar or plate strength cannot be produced especially for each test, variation of $\lambda$ values with respect to mortar or plate compressive strengths were analyzed and for every test, $\lambda$ values that best matches the results of experiments were obtained and best fit lateral load-top displacement curves were drawn. From the best fit curves, lateral load carrying capacity of the second strut modelling the strengthening layer of mortar and strengthening layer of plate can be calculated using equation 5 and equation 6 , respectively:

$$
\begin{aligned}
& F_{c}=4 \cdot\left(f_{c, \text { mortar }}\right)^{-0.75} \cdot a_{\text {mortar }} \cdot b_{w, \text { mortar }} \\
& F_{c}=7 \cdot\left(f_{c, \text { plate }}\right)^{-0.75} \cdot a_{\text {plate }} \cdot b_{w, \text { plate }}
\end{aligned}
$$

The load-deformation curve of the second compression strut modelling the plain/ $2 \%$ steel fiber reinforced mortar and precast RC rectangular/strip plate as a strengthening layer is illustrated in Figure 10.

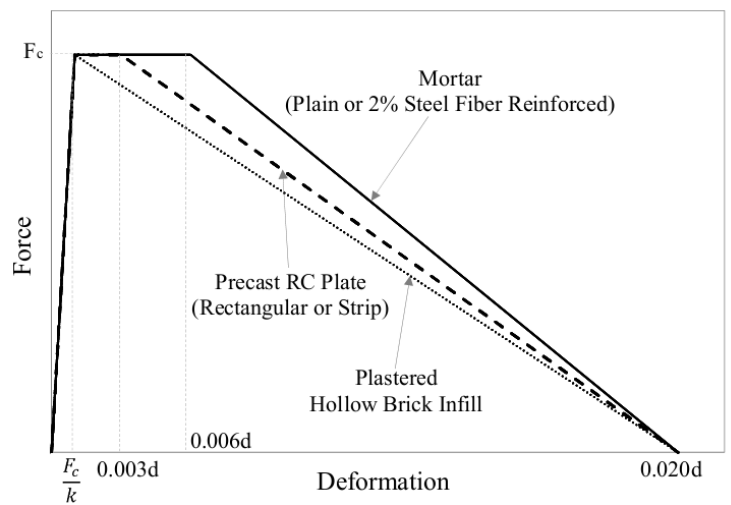

Figure 10 Force - deformation curves of compression struts.

\subsection{Design example of a strengthened building - A case study}

A building located in İstanbul, Zeytinburnu was evaluated using the strengthening techniques described in the previous sections. Location of the building exists on one of the seismically active zones of the city. Plan view, column and beam sections and details of strengthening techniques are illustrated in Figure 11 The building consists of five storey (one basement, three floors, one penthouse). Performance evaluation of the building is based on non-linear pushover analysis. Turkish Building Earthquake Code (2018) requires at least of eleven earthquake records to be defined in agreement with the elastic acceleration spectrum to effect from ground model base to one dimensional layered ground model. For this purpose, eleven different ground motion assemblies are selected for the non-linear analysis by 
considering parameters such as effects of near and far faults, magnitude of the ground motions, type of soil and mechanism of the fault. Ground motions were scaled using simple scaling methods in accordance with the horizontal elastic design spectrum. The three-dimensional (3D) computer model of the building was generated by using SAP 2000 (Version 8.1.2001) (CSI, 2001) program for the nonlinear static pushover analyses for estimating the building's displacement capacity.

From concrete core samples and steel coupons taken from each floor of the building, uniaxial compressive strength of $14 \mathrm{MPa}$ and a modulus of elasticity of $18900 \mathrm{MPa}$ for concrete were obtained, whereas yield strength of steel was calculated to be $220 \mathrm{MPa}$. Since the building was constructed in mid 1980s, low concrete compressive and steel yield strengths are related to extremely low construction quality together with the absence of a strict inspection system at the time of its construction. The building has a dimension of $6.8 \mathrm{~m}$ in $\mathrm{x}$ direction and $10.2 \mathrm{~m}$ in y direction. Beams and columns had dimensions of $200 \times 500 \mathrm{~mm}$ and $250 \times 400 \mathrm{~mm}$, respectively. Spacing of stirrups is $230 \mathrm{~mm}$ for all beams and $260 \mathrm{~mm}$ for all columns for both of which the requirement of the current Turkish Building Earthquake Code (2018) is not satisfied. Slab thicknesses were taken as $100 \mathrm{~mm}$. The stairs were not modelled whereas the stair spaces were. Inner hollow brick infill walls had a thickness of $135 \mathrm{~mm}$ (including plaster) and applied a distributed loading on beams as $220 \mathrm{~kg} / \mathrm{m}^{2}$ where these values were $250 \mathrm{~mm}$ (including plaster) and $240 \mathrm{~kg} / \mathrm{m}^{2}$ for outer hollow brick infill walls, respectively. Soil-structure interaction was not considered meaning that the building was accepted to be fixed in the analyses. Elastic design spectrum graphs were obtained for the earthquake ground motion level as DD-2 (10\% probability of exceedance in 50 years (return period of 475 years)) and the soil type ZD (Medium-dense to dense sand, gravel, or very stiff clay layers) was used in accordance with the Turkish Building Earthquake Code (2018). Short period design spectral acceleration coefficient SDS (dimensionless) was obtained as 1.102, design spectral acceleration coefficient (dimensionless) for a period of 1.0 seconds, $\mathrm{S}_{\mathrm{D} 1}$ was obtained as 0.567 and peak ground acceleration of the ground motion were obtained as $0.411 \mathrm{~m} / \mathrm{s}^{2}$ using the interactive web application of Turkey earthquake hazard maps provided by disaster and emergency management presidency. A map which shows the Zeytinburnu district together with the peak ground accelerations of the region is given in Figure 12.

Based on the analyses of the structural system members, load combination including the earthquake effect defined in Turkish Building Earthquake Code (2018) is given in Equation 7:

$G+Q+0.2 S+E_{d}^{(H)}+0.3 E_{d}^{(Z)}$

where $G$ is the effect of dead load, $Q$ is the effect of live load, $S$ is the effect of wind load, $E_{d}{ }^{(H)}$ is the horizontal earthquake effect based on the design with strike coupling applied and $E_{d}{ }^{(z)}$ is the earthquake effect under the effect of earthquake in (Z) direction.
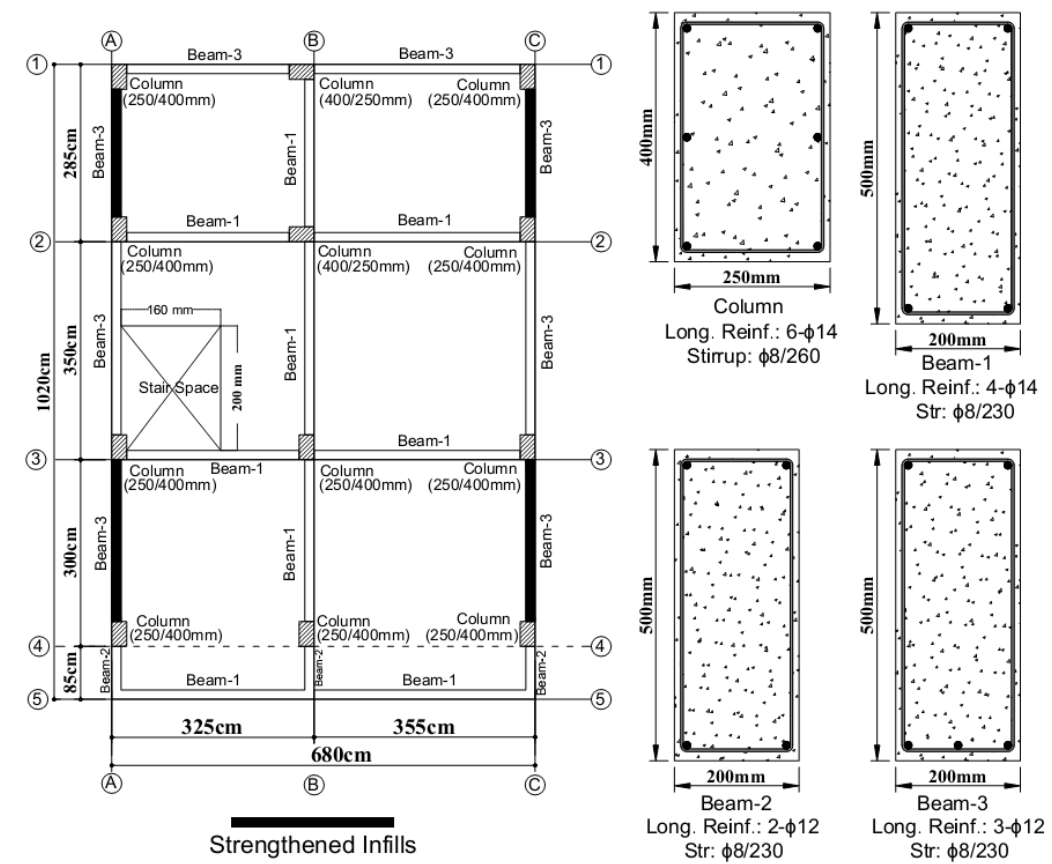

Figure 11 Plan view, column and beam sections and details of strengthening techniques. 


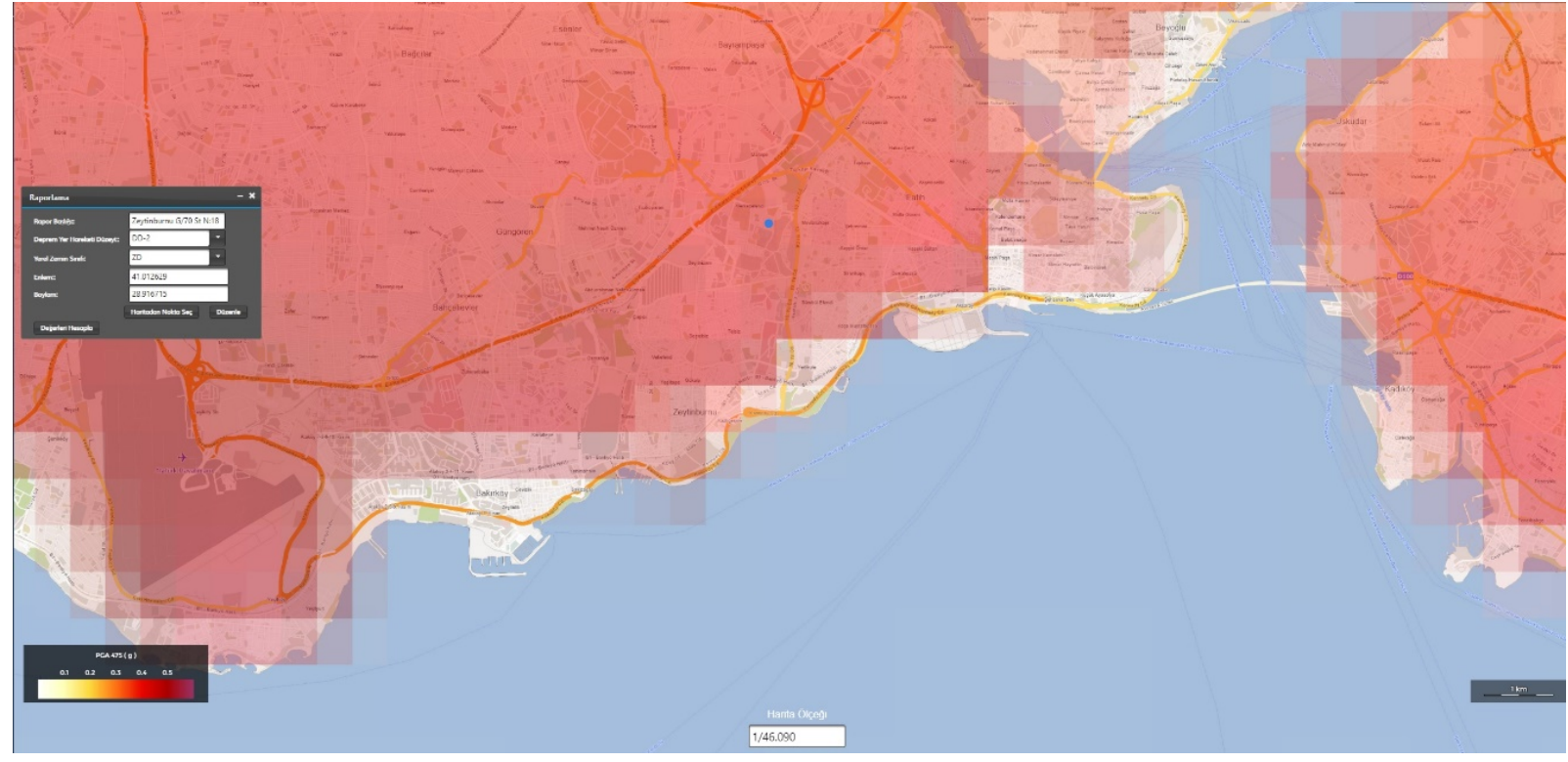

Figure 12 Zeytinburnu district and peak ground accelerations of the region.

The evaluation of the deficient building indicated that $75 \%$ of the first storey columns came out to be at the prevention of failure performance level according to which this building must be strengthened (Turkish Building Earthquake Code 2018). The strengthening techniques described in previous sections were applied to this building. Mortar and plate techniques were applied as diagonal compression struts whereas RC infill was applied using finite element method (shell element). Concrete strength and thickness were determined as $20 \mathrm{MPa}$ and $40 \mathrm{~mm}$ for mortar whereas $35 \mathrm{MPa}$ and $30 \mathrm{~mm}$ for plate, in order to satisfy the immediate usage performance level for the building in accordance with the Turkish Building Earthquake Code (2018). The interstorey drift ratios obtained from pushover analysis at performance points of the applied earthquake ground motion are shown in Figure 13. The highest interstorey drift ratio occurred at the second-floor level of the unstrengthened deficient building at a value of $2.0 \%$. Upon strengthening application, this ratio reduced to $0.49 \%$ for RC infill, $0.57 \%$ for plate strengthening and $0.60 \%$ for $\mathrm{mortar}$ strengthening showing that the strengthening techniques are obviously successful in controlling interstorey drift ratio demands and preventing collapse.
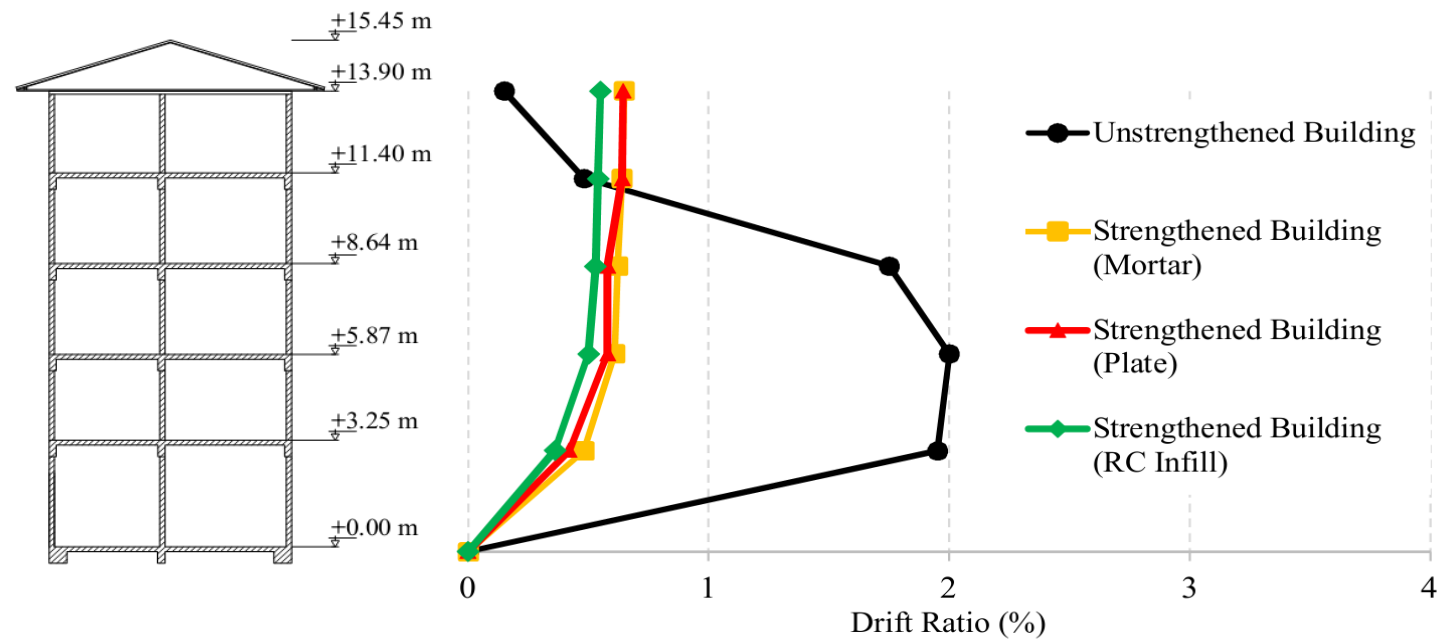

Figure 13 Inter storey drift ratios obtained from pushover analysis. 


\section{CONCLUSIONS}

In the present study, behaviour of non-ductile one-third scale RC frames having inadequate lateral stiffnesses strengthened by five different techniques were tested experimentally under reversed cyclic lateral loads. In the numerical analysis part, an existing RC non-ductile building having inadequate stiffness located in Istanbul and strengthened with the aforementioned techniques were modelled and analyzed using a computer program. The following conclusions can be drawn in the light of experimental and numerical studies conducted:

- Concrete compressive strengths of all test frames were calculated to be in the range of 12-15 MPa, except from Test frame-2 which have a value of $8.6 \mathrm{MPa}$. This low concrete compressive strength value can be attributed to curing conditions, temperature difference on casting days and water content difference of aggregate kept outside the laboratory which was exposed to outer climate conditions.

- Application of mortar (plain or $2 \%$ steel fiber reinforced) or bonding of precast RC plate (rectangular or strip) on plastered hollow brick infill retarded the early out of plane failure of the wall and converted the existing nonstructural infill into load carrying wall.

- All strengthening techniques significantly increased lateral load carrying capacities and rigidities as well as improved overall seismic behaviour of test specimens.

- The increase in lateral load carrying capacities of the strengthened test frames ranged from $57 \%$ to $194 \%$ with respect to the reference frame. The largest increase was observed in Test Frame- 4 which was strengthened with precast $\mathrm{RC}$ rectangular plates whereas the smallest increase was observed in Test Frame-2 which was strengthened with plain mortar. Relatively low increase in lateral load carrying capacity of Test frame-2 can be attributed to the very low concrete compressive strength of this frame.

- The increase in initial stiffnesses of the strengthened test frames ranged from $186 \%$ to $486 \%$ with respect to the reference frame. The largest increase was observed in Test Frame- 6 which was strengthened with RC infill whereas the smallest increase was observed in Test Frame- 2 which strengthened with plain mortar.

- The increase in the energy dissipation capacities of the strengthened test frames ranged from $110 \%$ to $378 \%$ with respect to the reference frame. The largest increase was observed in Test Frame- 6 which was strengthened with RC infill whereas the smallest increase was observed in Test Frame-3 which was strengthened with $2 \%$ steel fiber reinforced mortar.

- Storey drift index was reduced as a result of applied strengthening techniques. The limit value specified by the Turkish Building Earthquake Code (2018) seems to be appropriate for strengthened RC frames.

- The smallest increase in lateral strength and stiffness was observed in Test Frame-2 for which plain mortar was introduced. The weak adhesion capability of the mortar prevented the test frame carrying higher lateral loads and shear forces despite the high compressive strength of plain mortar. Test Frame-3, for which $2 \%$ steel fiber reinforced mortar was introduced, behaved better as compared to Test Frame-2 due to possible existence of steel fibers reinforcing the plain mortar.

- The increase in lateral load carrying capacities of Test Frame-4 and Test Frame-5 which were strengthened by precast RC rectangular and strip plates respectively, came out to be as superior as Test Frame- 6 which was strengthened with RC infills. This was due to the fact that the strong two-component epoxy turned the plastered infill into a rigid infill-epoxy-plate trio behaving like an RC infill in both specimens. Test Frame-6 obtained better results with respect to initial stiffness and energy dissipation capacity points of view.

- $\quad$ Although Test Frame-4 and Test Frame-5 showed superior behaviour as Test Frame-6 from lateral load carrying capacity point of view, they could not be able to make much more cycles after reaching to their ultimate loads, as in the case of Test Frame-6. More simply, they could not be able to behave as a cantilever beam. This can be attributed to anchorage bars used only at the foundation level for both specimens (TF-4 and TF-5). Therefore, complete use of anchorage bars at four sides of both stories seems to be essential for a more ductile behaviour due to better transfer of shear forces between infill-RC frame.

- Application of plain/2\% steel fiber reinforced mortar and precast RC rectangular/strip plate techniques can be called as occupant-friendly simply because minimum disturbance is given to occupants during the application of the techniques. Especially in plate technique, occupants are less disturbed as compared to mortar technique because plates are manufactured as precast at the plant where the mortar layer is spread on the plaster inside the apartment house. Covering the plaster with epoxy is much tidier than spreading mortar on the plaster of the infill. 
- In order to reach the performance level to that of RC Infill strengthening technique (upper bound), different compressive strengths for mortar and concrete was targeted at every strengthening technique. For mortar based strengthening (plain/2\% steel fiber reinforced mortar), a minimum mortar compressive strength of $40 \mathrm{MPa}$ was targeted. For plate based strengthening, a minimum concrete compressive strength of $30 \mathrm{MPa}$ was targeted whereas a minimum of $25 \mathrm{MPa}$ was targeted for RC Infill strengthening. The target strength was chosen to be higher as compared to the others in mortar based strengthening since there is no any other agent for the application of mortar on the plaster, except from the mortar itself. However, the target strength was lowered to $30 \mathrm{MPa}$ in plate based strengthening since a strong two-component epoxy was used for bonding of plates on the plaster where the epoxy agent would turn the plastered infill into a rigid infill-epoxy-plate trio. The target strength was chosen to be as $25 \mathrm{MPa}$ in RC Infill strengthening technique since this technique forms the upper bound for the others due to effective anchoring of the infill to RC Frame.

- From the economy point of view, the most advantageous technique is the use of plain $/ 2 \%$ steel fiber reinforced mortar because national materials are used during application. This economy point of view also holds true for RC infill wall technique. However, although the strength increase reaches the performance level of RC infill technique as well as the improved overall seismic behaviour, two-component epoxy is expensive due to being an export material. This makes the total cost of precast RC plate application costlier as compared to other techniques and makes the technique in advantageous. Complete use of anchorage bars at four sides of both stories seem to be essential for an improved behaviour (monolithic RC frame-infill wall behaviour). By this way, total cost can increase to some extent due to workmanship and material expense of additional anchorage bar embedment however a more ductile behaviour can be obtained instead.

- $\quad$ All the strengthening techniques do not require a qualified workmanship during manufacturing of materials and application of techniques. However, attention should be paid during covering the plastered infill with epoxy, plate manufacturing and cleaning of anchorage dowels.

- Numerical studies conducted on an existing non-ductile RC building having low strength concrete and inadequate stiffness showed that the techniques will increase the lateral strength and stiffness of the building. Plain/2\% steel fiber reinforced mortar and precast RC rectangular/strip plate techniques came out to be successful in controlling the drift ratios and demands in the column members. For some deficient buildings, all practically applicable strengthening techniques explained in the present study can obviously prevent collapse.

Editor: Marcílio Alves

\section{References}

Acun, B. Sucuoglu, H., (2005). Tuğla dolgu duvarlı çerçevelerin hasır donatı ile güçlendirilmesi. Earthquake Symposium, Kocaeli, Turkey (in Turkish).

Akhoundi, F., Vasconcelos, G., Lourenço, P., Silva, L.M., Cunha, F., Fangueiro, R., (2018). In-plane behavior of cavity masonry infills and strengthening with textile reinforced mortar. Engineering Structures 156: 145-160.

Akin, A., Sezer, R., (2016). A Study on Strengthening of Reinforced Concrete Frames Using Precast Concrete Panels, KSCE Journal of Civil Engineering 20: 2439-2446.

Akin, E., Canbay, E., Binici, B., Ozcebe, G., (2011). Testing and Analysis of Infilled Reinforced Concrete Frames Strengthened with CFRP Reinforcement. Journal of Reinforced Plastics and Composites. 30(19): 1605-1620.

Aksoylu, C., Kara, N., (2020). Strengthening of RC Frames by using High Strength Diagonal Precast Panels. Journal of Building Engineering 31: 101338.

Aksoylu, C., Sezer, R., (2018). Investigation of Precast New Diagonal Concrete Panels in Strengthening the Infilled Reinforced Concrete Frames. KSCE Journal of Civil Engineering 22: 236-246.

Allahabadi, R., Powell, G. H., (1988). DRAIN-2DX User Guide, Report No. UCB/EERC-88/06, University of California, Berkeley, California, USA.

Altin, S., Anil, O., Kara, M.E., Kopraman, Y., (2012). Comparison of Seismic Performances of RC Frames Strengthened with Four Different Techniques. Advances in Structural Engineering 15(2): 343-357. 
Altin, S., Anil, O., Kopraman, Y. Belgin, C., (2010). Strengthening masonry infill walls with reinforced plaster. Proceedings of the Institution of Civil Engineers-Structures and Buildings 163(5): 331-342.

Altin, S., Anil. Ö., Kara, M.E., Kaya, M., (2008a). An Experimental Study on Strengthening of Masonry Infilled RC Frames using Diagonal CFRP Strips. Composites Part B 39(4): 680-693.

Altin, S., Kuran, F., Anil, O., Kara, M.E., (2008b). Rehabilitation of Heavily Earthquake Damaged Masonry Building Using Steel Straps. Structural Engineering and Mechanics 30(6): 651-664.

Antoniades, K.K., Salonikios, T.N., Kappos, A.J., (2005). Tests on Seismically Damaged Reinforced Concrete Walls Repaired and Strengthened Using Fiber-Reinforced Polymers. Journal of Composites for Construction 9(3): 236-246.

Askouni, P.D., Papanicolaou, C.G., (2017). Experimental investigation of bond between glass textile reinforced mortar overlays and masonry: The effect of bond length. Materials and Structures 50 (2): 164.

Baran, M., Canbay, E., Tankut, T., (2010). Seismic Strengthening with Precast Concrete Panels - Theoretical Approach. Technical Journal 21(2): 4959-4978 (in Turkish).

Baran, M., Ozcelik, R., Sevil, T., Canbay, E., (2013). Modelling of Strengthened Hollow Brick Infills. Magazine of Concrete Research 65(4): 257-271.

Baran, M., Sevil, T., (2010). Analytical and Experimental Studies on Infilled RC Frames. International Journal of the Physical Sciences 5(13): 1981-1998.

Baran, M., Tankut, T., (2011a). Experimental Study on Seismic Strengthening of RC Frames by Precast Concrete Panels. ACl Structural Journal 108(2): 227-237.

Baran, M., Tankut, T., (2011b). Retrofit of Non-Ductile RC Frames with Precast Concrete (PC) Wall Panels. Advances in Structural Engineering 14(6): 1149-1166.

CSI (Computers and Strutures Inc.) (2001). SAP2000, version 8.1.(2001), SAP2000 Integrated Finite Element Analysis and Design of Structures, Berkeley, California, USA.

De Felice, G., De Santis, S., Garmendia, L., Ghiassi, B., Larrinaga, P., Lourenço, P.B., Oliveira D.V., Paolacci, F., Papanicolaou, C.G., (2014). Mortar-based systems for externally bonded strengthening of masonry. Materials and Structures 47 (12): $2021-$ 2037.

El-Dakhakhni, W.W., Hamid, A.A., Hakam, Z.H.R., Elgaaly, M., (2006). Hazard mitigation and strengthening of unreinforced masonry walls using composites. Composite Structures 73(4): 458-477.

ElGawady, M., Letuzzi, P., Badoux, M., (2004). A review of conventional seismic retrofitting techniques for URM. In: 13th international brick and block masonry conference, Amsterdam.

ElGawady, M.A., Lestuzzi, P. Badoux, M., (2006a). Retrofitting of masonry walls using shotcrete. Proceedings of New Zealand Society for Earthquake Engineering Conference, Napier, New Zealand.

ElGawady, M.A., Lestuzzi, P., Badoux, M., (2006b). Aseismic Retrofitting of Unreinforced Masonry Walls Using FRP. Composites Part B 37: 148-162.

Erdem, İ., Akyüz, U., Ersoy, U., Özcebe, G., (2006). An Experimental Study on two Different Strengthening Techniques for RC Frames. Engineering Structures. 28(13): 1843-1851.

Farooq, S.H., Ilyas, M., Ghaffar, A., (2006). Technique for Strengthening of Masonry Wall Panels Using Steel Strips. Asian Journal of Civil Engineering 7(6): 621-638.

FEMA 356 (2000). Federal Emergency Management Agency - Prestandard and Commentary for the Seismic Rehabilitation of Buildings.

Frosch, R.J., (1999). Panel Connections for Precast Concrete Infill Walls. ACl Structural Journal 96(4): 467-474.

Frosch, R.J., Li, W., Jirsa, J.O., Kreger, M.E., (1996). Retrofit of Non-ductile Moment-Resisting Frames using Precast Infill Wall Panels. Earthquake Spectra 12(4): 741-760.

Garcia, R., Hajirasouliha, I., Pilakoutas, K., (2010). Seismic Behaviour of Deficient RC Frames Strengthened with CFRP Composites. Engineering Structures 32(10): 3075-3085. 
Hadigheh, S.A., Mahini, S.S., Maheri, M.R., (2014). Seismic Behavior of FRP-Retrofitted Reinforced Concrete Frames. Journal of Earthquake Engineering 18(8): 1171-1197.

Kahn, L.F., (1984). Shotcrete Strengthening of Brick Masonry Walls. ACI Structural Journal 6(7): 34-40.

Kahn, L.F., Hanson, R.D., (1979). Infilled Walls for Earthquake Strengthening. Journal of the Structural Division 105(2): $283-296$.

Kaldjian, M.J., Yuzugullu, O., (1983). Efficiency of Bolt Connected Shear Panels to Strengthen Building Structures. The First International Conference on Concrete Technology for Developing Countries, Yarmouk University, Irbid, Jordan.

Kesner, K., Billington, S.L., (2005). Investigation of Infill Panels Made From Engineered Cementitious Composites for Seismic Strengthening and Retrofit. Journal of Structural Engineering 131(11): 1712-1720.

Korkmaz, S.Z., Kamanli, M., Korkmaz, H.H., Donduren, M.S., Cogurcu, M.T., (2010). Experimental Study on the Behavior of Nonductile Infilled RC Frames Strengthened with External Mesh Reinforcement and Plaster Composite. Natural Hazards and Earth System Sciences 10: 2305-2316.

Koutas, L., Pitytzogia, A., Triantafillou, T.C., Bousias, S.N., (2014). Strengthening of infilled reinforced concrete frames with textile-reinforced mortar (TRM): Study on the development and testing of textile-based anchors. Journal of Composites for Construction 18(3): A4013015.

Koutas, L.N., Bournas, D.A., (2019). Out-of-Plane Strengthening of Masonry-Infilled RC Frames with Textile-Reinforced Mortar Jackets. Journal of Composites for Construction 23(1).

Koutas, L.N., Tetta, Z., Bournas, D.A., Triantafillou, T.C., (2019). Strengthening of concrete structures with textile reinforced mortars (TRM): State-of-the-art review. Journal of Composites for Construction 23(1).

National Information Centre for Earthquake Engineering, (1986). Guidelines for Earthquake Resistant Non-Engineered Construction. Chapter 9: Repair Restoration and Strengthening of Buildings.

Okuyucu, D., (2011). Effects of Frame Aspect Ratio on the Seismic Performance Improvement of Panel Strengthening Technique. Ph. D. Thesis, The Graduate School of Natural and Applied Sciences, METU, Turkey.

Oliveira, D.V., Silva, R.A., Garbin, E., Lourenco, P.B., (2012). Strengthening of Three-Leaf Stone Masonry Walls: An Experimental Research. Materials and Structures 45(8): 1259-1276.

Ozbek, E., Can, H., (2012). Dolgu tuğla duvarların çelik profillerle güçlendirilmesi. Gazi Üniversitesi Mühendislik Mimarlık Fakültesi Dergisi 27(4): 921-929 (in Turkish).

Ozcebe, G., Ersoy, U., Tankut, T., Erduran, E., Keskin, R.S.O., Mertol, H.C., (2003). Strengthening of brick infilled RC frames with CFRP. SERU-Structural Engineering Research Unit, Report No. 2003/1, TUBITAK-METU, Ankara, Turkey.

Papanicolaou, C.G., Triantafillou, T.C., Karlos, K., Papathanasiou, M., (2007). Textile-reinforced mortar (TRM) versus FRP as strengthening material of URM walls: In-plane cyclic loading. Materials and Structures 40(10): 1081-1097.

Papanicolaou, C.G., Triantafillou, T.C., Papathanasiou, T.C., Karlos, K., (2008). Textile-reinforced mortar (TRM) versus FRP as strengthening material of URM walls: Out-of-plane cyclic loading. Materials and Structures 41 (1): 143-157.

Raoof, S.M., Bournas, D.A., (2017a). Bond between TRM versus FRP composites and concrete at high temperatures. Composites Part B 127: 150-165.

Raoof, S.M., Bournas, D.A., (2017b). TRM versus FRP in flexural strengthening of RC beams: Behaviour at high temperatures. Construction Building and Materials 154: 424-437.

Sevil, T. (2010). Seismic Strengthening of Masonry Infilled R/C Frames with Steel Fiber Reinforcement, Ph. D. Thesis, Middle East Technical University, Turkey.

Sevil, T., Baran, M., Bilir, T., Canbay, E., (2011). Use of Steel Fiber Reinforced Mortar for Seismic Strengthening. Construction and Building Materials 25(2): 892-899.

Sika, (2001). Sikadur-31 SBA Type S-07, 7-2001, Segmental Bridge Adhesive, Product Data Sheet. Sika, UK.

Smith, B.S., Carter, C., (1969). A Method of Analysis for Infilled Frames. Proceedings of the institution of civil engineers 44: $31-$ 48.

Spit Epcon System (2005). Specifications, Definition, Applications, Installation. Fixing of Rebars for Concrete, SOCOTEC, France. 
Taghdi, M., Bruneau, M., Saatcioglu, M., (2000a). Analysis and design of low-rise masonry and concrete walls retrofitted using steel strips. Journal of Structural Engineering 126(9): 1026-1032.

Taghdi, M., Bruneau, M., Saatcioglu, M., (2000b). Seismic retrofitting of low-rise masonry and concrete walls using steel strips. Journal of Structural Engineering 126(9): 1017-1025.

Tetta, Z.C., Bournas D.A., (2016). TRM vs FRP jacketing in shear strengthening of concrete members subjected to high temperatures. Composites Part B 106: 190-205.

Triantafillou, T.C., Papanicolaou, C.G., (2006). Shear strengthening of reinforced concrete members with textile reinforced mortar (TRM) jackets. Materials and Structures 39 (1): 93-103.

Turkish Building Earthquake Code (2018). Disaster and Emergency Management Presidency, Ministry of Interior, Ankara, Turkey.

Zhu, J.T., Wang, X.L., Xu, Z.D., Weng, C.H., (2011). Experimantal Study on Seismic Behavior of RC Frames Strengthened with CFRP Sheets. Composite Structures 93(6): 1595-1603. 